\title{
THE SITUATION OF THE HISTORICAL CHURCHES, ESPECIALLY OF THE GREEK CATHOLIC CHURCH IN TRANSCARPATHIA AT THE TIME OF THE ESTABLISHMENT OF THE SOVIET SYSTEM
}

\section{Varadi N. F.}

\section{Introduction}

Churches and faith play an important role in the life of a nation and man. During the Soviet period, churches and religions disturbed communist atheism merely with their existence. One of the main goals of the all-powerful, dictatorial Soviet communist leadership was to reduce the number of believers, to make the activities of churches impossible, or at least to limit them to the matters of faith and the faithful ${ }^{1}$. A significant portion of religious holidays were either abolished or filled with new content.

\section{Persecution of Christians and God believers in Transcarpathia}

Transcarpathia came under Soviet control from September 26 to October $28,1944^{2}$. The Hungarians of Transcarpathia, detached from Hungary, endured many troubles since the end of World War II due to the dictatorial measures of the Soviet authorities. As the Red Army approached, as early as the summer of 1944, officers, officials, teachers, railway officers, church leaders, and so on began moving out of the region ${ }^{3}$.

On November 19, 1944, in Mukachevo, communists convened the first Transcarpathian Party Conference, where they formed the

${ }^{1}$ Bohán B. Adalékok a Szatmári Egyházmegye XX. századi történetéhez. Magyar Egyháztörténeti Vázlatok. 2007. № 19. Évf. 3-4. Szám. 113-142.

${ }^{2}$ Botlik J. Hármas kereszt alatt. Görög katolikusok Kárpátalján az Uzhhorodi uniótól napjainkig (1946-1997). Hatodik Síp Alapitvány. Budapest: Új Mandátum Könyvkiadó, 1997. $274 \mathrm{ol}$.

${ }^{3}$ Fodor G. Kárpátalja szovjetizálásának hatásai a Kárpátaljai Református Egyház életére 1944-1954 között. Szovjet fogságba hurcolt reformátusok a Kárpát-medencében. Tanulmánykötet / Erdős K. et al. (ed.). Debrecen, 2017. Ol. 181-182; Móricz K. Kárpátalja Sorsfordulói. Budapest: Hatodik Síp Alapítvány, 2001. 140 ol. 
Communist Party of Transcarpathian Ukraine, proclaimed the independence of Transcarpathian Ukraine, and adopted a resolution to "reunite" the territory with Soviet Ukraine, and on November 26, at the first congress of the People's Committee 663 delegates voted in favour of the resolution in the presence of the armed squads of the $\mathrm{NKVD}^{4}$. In addition, the Congress passed a resolution on the division of large estates, ecclesiastical lands, elected the People's Council of Transcarpathian Ukraine as the only central power in the area operating "by the will of the people", chaired by Ivan Turianytsia 5 . Stalin informed the Czechoslovak leadership that he could not oppose the will of the people, and Turianytsia called on the Czechoslovak government delegation based in Khust to leave the territory of Transcarpathia. According to Soviet data, by January 1, 1945, more than 250,000 Transcarpathian residents had "voluntarily" signed the Mukachevo Manifesto requesting "reunification",

On June 29, 1945, in Moscow, the Czechoslovak and Soviet governments signed a treaty on the final handover of Transcarpathia in Russian, Ukrainian, and Slovak languages. The treaty was signed on the Soviet side by Vyacheslav Molotov, Vice-President of the Council of People's Commissioners of the Union of Soviet Socialist Republics, People's Commissar for Foreign Affairs, and Prime Minister Zdenek Fierlinger and Foreign Minister Vladimír Klementis ${ }^{7}$ on behalf of the Czechoslovak Republic. The document was ratified by the Provisional National Assembly of Czechoslovakia on November 22, 1945, and by the Presidency of the Supreme Soviet of the Soviet Union on November 27. From January 22, 1946, the Presidency of the Supreme Soviet of the Soviet Union transformed the Ukrainian SSR into a typical Soviet county, merging the region as the Transcarpathian Territory (Закарпатська область) into the Soviet administrative system ${ }^{8}$, which it belonged to until 1991 i. e. until the collapse of the Soviet Union.

${ }^{4}$ Homeland Security Office (Russian: НКВД, Народный комиссариат внутренних дел).

${ }^{5}$ Botlik J. Hármas kereszt alatt... O1. 274.

${ }^{6}$ Botlik J. Egestas Subcarpathica. Adalékok az Északkeleti-Felvidék és Kárpátalja XIX-XX. Századi történetéhez. Budapest: Hatodik Síp Alapítvány, 2000. O1. 285-286.

7 Vida I., Zseliczky B. Az 1945. június 29-ei szovjet - csehszlovák szerződés Kárpátaljáról. Külügyi Szemle. 2004. Tavasz - nyár. Ol. 252.

8 Botlik J. Hármas kereszt alatt... O1. 276; Oficinszkij R. A szovjet időszak sajátosságai Kárpátalja történetében. Kárpátalja 1919-2009 történelem, politika, kultúra I Fedinec Cs., Vehes M. (eds.). Hely nélkül: Argumentum, MTA Etnikai-nemzeti Kisebbségkutató Intézete, 2010. O1. 217. 
Thus, as early as January 24, 1946, according to the decree of the Presidency of the Supreme Soviet of the USSR, the laws of the USSR came into force in the Transcarpathian region. Restrictions on the activities of religious communities were immediately tightened. State aid previously paid to pastors was cancelled. The total deprivation of the congregations of their property and the general impoverishment of the members imposed a great burden on the congregations ${ }^{9}$.

On December 5, 1944, mass secularization took place, declaring the separation of church and state, church and school. In the 1944-1945 school year, only one religion class per week was allowed $^{10}$.

In March 1945, the authority to register births, marriages, and deaths was taken away from churches and was made the responsibility of state bodies. The Decree on Family and Marriage played an important role in the line of legislative decrees of the People's Council. This allowed for a wedding without a church ceremony. A church wedding was only possible after the civil marriage ${ }^{11}$.

The decree No. 58 issued in Uzhhorod on April 20, 1945, stated, among other things, that the upbringing and education of youth in Transcarpathian Ukraine was the task of the state, the executive power was concentrated in the hands of the Public Education Commissioner of the People's Council ${ }^{12}$. Denominational schools were nationalized $^{13}$. Religious education was permanently banned. Anyone who broke the law could count on the harsh consequences. "Persons in the service of the cult who organized children into groups for the purpose of studying theology must be punished with the full rigor of Soviet laws!", - demanded F.M. Rasput'ko, the Transcarpathian County Councilor for the Affairs of Religious Cults, from Chopey, the county attorney general ${ }^{14}$. Nevertheless, church

9 Fodor G. A Kárpátaljai református egyház élete a sztálini egyházpolitika szorításában. A kommunizmus áldozatai, rehabilitációs alternativak Kelet-Közép Európában / Molnár D. E., Molnár D. I. Berehove: II. Rákóczi Ferenc Kárpátaljai Magyar Föiskola, 2016. Ol. 181.

${ }^{10}$ Botlik J. Hármas kereszt alatt... Ol. 276.

${ }^{11}$ Oficinszkij R. A szovjet időszak... Ol. 288.

12 Fedinec Cs. Fejezetek a kárpátaljai magyar közoktatás történetéből (1938-1991). Nemzetközi Hungarológiai Központ. Budapest, 1999. Ol. 38.

${ }^{13}$ Transcarpathian Regional State Archives. Fond P-14. Op. 1. Od. zb. 1. «a».

${ }^{14}$ Central State Archive of the highest authorities and administration of Ukraine. F. 4648. Op. 4. Od. zb. 214. P. 74-77. 
education took place in numerous locations, which was severely punished by the Soviet authorities ${ }^{15}$.

Churches were not considered legal entities. In 1945-1946, ecclesiastical, parochial, and denominational school property was completely nationalized. Congregations had to rent their own former churches from the state, and various taxes were imposed on them. If the tax had not been paid, the church was closed ${ }^{16}$. People living at church schools, convents, parishes were evicted. In several places pastors and priests lived in rented accommodation. If a settlement wanted to keep its church, a large tax was imposed on it ${ }^{17}$. It became common that churches were transformed into atheist museums, gyms, clubs, warehouses, and workshops ${ }^{18}$.

One particular form of atheist education was individual education of schoolchildren who were presumably from strongly religious families. It was a constant task for educators to portray churches as anti-progressive and anti-scientific in their classes ${ }^{19}$. A teacher, a person in a uniform, a person working in a senior position was not allowed go to church.

Several villages fought against the closure of their churches, so the leadership of the Transcarpathian County Committee of the UCP demanded even stronger action from local Soviet leaders. [...] "The local party organization must be strengthened and the opposers must be

${ }^{15}$ Excerpt from a report by Kormos V. I., Secretary of the UCP Vynohradiv District Committee, dated 20 August 1957: "[...] As a result of our hard work, part of the population was liberated from religion. I must say, however, that intelligence only takes up a very small part of the work in anti-church propaganda [...] I have to say that sectarians, Roman Catholics, Reformed people have become active in the villages of our district. They try to influence youth, they strive for young people to go to church and teach them religion. They want to dismantle the Komsomol organizations. In Perekhrestia, the priest, Szabo, founded a Sunday school, which Komsomol members attend as well. He organized a dance party where the local Komsomol secretary danced with a girl. [...] Erzsébet Rebenyák teaches religion in her own apartment in Vylok. And in several villages [...] no anti-church activities are performed, so the Komsomols who have not been to church before, are now regular visitors [...]. Anti-church propaganda must be increased and more lectures on anti-church topics must be held [...]». Transcarpathian Regional State Archives. F. 454. Op. 7. Ed. hr. 4. P. 114.

${ }^{16}$ Botlik J. Hármas kereszt alatt... Ol. 279.

17 Élő történelem. A Sztálini haláltáborok túlélőinek vallomásai 1944-1957 / Dupka G. (ed.). Uzhhorod - Budapest: Intermix Kiadó, 1993. Ol. 39; Bohán B. SJ: Adalékok a Szatmári... Ol. 113-142; Dupka G. Koncepciós perek magyar elitéltjei. A sztálinizmus áldozatainak emlékkönyve (1944-1957). Uzhhorod-Budapest: Intermix Kiadó, 1993. O1. 39.

${ }^{18}$ Majnek A. A Kárpátaljai római katolikus egyház története / Tóth I. et al. (eds.), Uzhhorod: Útközben. Tanulmányok a kárpátaljai magyarságról, 1998. O1. 55.

${ }^{19}$ Oficinszkij R. A szovjet időszak... O1. 288. 
held accountable, the church must be closed and transformed into a cultural space $[\ldots] !, 20$, - the instruction stated.

A significant part of the priests and pastors were imprisoned or taken to the Gulag, so the ones who stayed at home served in 3-4 villages. They mostly traveled between their congregations on foot or by bicycle both in winter and summer, in old clothing and worn-out shoes.

Religious ceremonies outside the church, such as pilgrimages, processions, confirmation, and so on, were banned. Religious evenings could only be held on Sundays and public holidays as part of a church mass ${ }^{21}$.

Later, if the village community voted in favour, every church member over the age of 18 could donate the salary that he received in the kolkhoz for one working day to the pastor, which was not a large amount and, due to the scarce times, was not even supported in many settlements ${ }^{22}$.

The Transcarpathian Investigation Department of the State Security Office of the Ukrainian SSR constantly monitored the pastors and priests, collected data on them and sent reports to the Council of Religious Cults. Active members of the church were also constantly monitored $^{23}$. They selected the right people for these jobs, who carried out their instructions and made reports about parishioners, church people, and what the priest and pastor talked about during the mass or worship ${ }^{24}$. Provocators were dismantling the church. The priests were being compromised. ${ }^{25}$ They sought to increase the effectiveness of both open and secret actions through arrests and strong agitation and propaganda activities, and perpetuated the "proletarian dictatorship" 26 .

At regular intervals, usually every six months, but sometimes even more often, churches had to report on various church-related events, such as: how many people visited the church at Easter, how many church visitors were there on Sundays, how many communioners were there,

${ }^{20}$ Transcarpathian Regional State Archives. F. 1. Op. 1. Delo Nr. 3485. P. 97-99.

${ }^{21}$ Archives of the Transcarpathian Reformed Diocese. Supreme Authority Circulars.

F. I. 10. C. February 4, 1957.

22 Archives of the Transcarpathian Reformed Diocese. Circulars. F. I. 10. C. December 4, 1961.

${ }^{23}$ Gulácsy L. A mélységből a magasba. Bizonyságtétel az elmúlt időkről. Magánkiadás. 2009. Ol. 61.

${ }^{24}$ Dupka G. Koncepciós perek magyar elitéltjei... O1. 99.

${ }^{25}$ Transcarpathian Regional State Archives. F. P-1490. Op. 1. Delo Nr. 1. P. 6-8.

${ }^{26}$ Botlik J. Egestas Subcarpathica... O1. 286. 
whether there was an organ or harmonium in the church, how many government bonds the church had ${ }^{27}$, and so on.

A separate report was requested on the consecration ceremonies, including a written record of the ceremony ${ }^{28}$, as well as reports on the renovations of the church, indicating the exact amounts and expenses ${ }^{29}$. No money was given for this purpose, and in fact, as far as it was possible, the renovation was being prevented, for example, the necessary official permits were not issued, but it was the task of the local pastor to rebuild the church from various donations, i. e. "people's money". Failure to do so would result in the church being closed as it could be in life threatening condition and an accident could happen at any time $\mathrm{e}^{30}$.

The High Commissioner for Religious Affairs demanded the book inventories of the churches and all other documents be translated into Russian, by an official Russian-speaking specialist who prepared the translation for a fee of 15 rubles per church. If the church did not have the money for the translation and the pastor sent the official documents in Hungarian, they were returned and often a penalty fee was imposed ${ }^{31}$.

Party secretaries were required to hold atheist propaganda lectures in all settlements ${ }^{32}$.

Despite the bans and persecutions, the churches were alive and operating, albeit in very difficult circumstances.

The relatively milder, though not much different, church policy that began after Stalin's death lasted from 1953 to 1958. Petro Vilkhovyi, leader of the Council of Religious Cults of the USSR, arrived in Uzhhorod on June 24, 1953. During his stay here, he drew attention to the need to place more emphasis on religious life and to have conversations with the leaders of the Transcarpathian denominations ${ }^{33}$.

27 Archives of the Transcarpathian Reformed Diocese. Administrative documents. F. I. 10. C. February 4, 1957.

${ }^{28}$ Archives of the Transcarpathian Reformed Diocese. Administrative documents. F. I. 10. C. February 2, 1956.

${ }^{29}$ Archives of the Transcarpathian Reformed Diocese. Supreme authority circulars.

F. I. 10. C. January 29, 1957.

${ }^{30}$ Transcarpathian Regional State Archives. F. P-1490. Op. 1. Delo Nr. 12. P. 6.

31 Archives of the Transcarpathian Reformed Diocese. Administrative documents. F. I. 10. C. February 14, 1957.

${ }^{32}$ Transcarpathian Regional State Archives. F. 454. Op. 7. Ed. hr. 6. P. 63.

${ }^{33}$ Central State Archive of the highest authorities and administration of Ukraine. F. 4648. Op. 4. Od. zb. 114. P. 22. 
It is a relevant fact that the priests and pastors were released by amnesty in 1955-1956 and returned home, to their places of service ${ }^{34}$ shortly before the outbreak of the 1956 revolution. This did not mean rehabilitation, only the suspension of the sentence. They came home but were under control. Most of them had nowhere to live, as the parishes became state property and performed other functions. They could only go to their relatives, but they could not settle where they wanted. Many did not take on further service because they became ill or felt too old. However, this also required state or police approval.

\section{The situation of the Greek Catholic Church and the life of Bishop Sandor Chira}

The independent Greek Catholic Eparchy of Mukachevo (Munkács in Hungarian) was established on September $19,1771^{35}$, by Pope Clement XIV. At the end of the $18^{\text {th }}$ century, the eparchy moved its headquarters from Mukachevo to Uzhgorod, but the adjective "of Mukachevo" remained in its name ${ }^{36}$.

The jurisdiction of the Greek Catholic Eparchy of Mukachevo covered 320 parishes between the two world wars, 265 of which operated in today's Transcarpathia. After the sudden death of Bishop Sándor Sztojka (1890-1943), the Holy See did not appoint a new bishop in 1943 due to the the war situation. The eparchy was temporarily ruled by Sándor Ilniczky (1889-1947), the great provost of the chapter ${ }^{37}$, then from January 1, 1944, as the front line approached, Dr. Miklós Dudás (1902-1972) of Hajdúdorog was appointed apostolic administrator by the Vatican ${ }^{38}$. Theodore Romzha (1911-1947), the then graduating priest, was ordained a bishop in the Uzhgorod Cathedral ${ }^{39}$ by Miklós Dudás, together with Roman Catholic pastor István Madarász from

${ }^{34}$ Central State Archive of the highest authorities and administration of Ukraine. F. 4648. Op. 4. Od. zb. 214. P. 27-36.

${ }^{35}$ Marosi I. Görögkatolikus Magyarok Kárpátalján. Nagybégány - Berehove: Szent Miklós Egyesület, 2014. Ol. 7.

${ }^{36}$ Gönczi A. Ruszin skizmatikus mozgalom a XX század elején. Uzhhorod - Berehove, 2008. Ol. 25.

${ }^{37}$ Пекар А. В. Нарис історії Церкви Закарпаття. Т. 1: Єрархічне оформлення. Рим - Львів, 1967. С. 193.

${ }^{38}$ Transcarpathian Regional State Archives. F. 151. Op. 24. Delo Nr. 964.

39 Dupka G. Egyházüldözés Kárpátalján 1944-1991. A Gulágra elhurcolt és megtorlásban részesült kárpátaljai római katolikus, görögkatolikus papok, református lelkipásztorok és más felekezetek vezetöinek emlékére. Uzhhorod - Budapest: Szolyvai Emlékparkbizottság - Intermix Kiadó, 2017. Ol. 51. 
Košice and János Seffer from Satu Mare on September 24, $1944^{40}$. In 1945, the eparchy chapter had 3 members: prelate Sandor Chira, Tivadar Kohutics and Viktor Choma ${ }^{41}$.

In 1944, the Red Army arrived in Transcarpathian Ukraine, which caused concern among the clergy. It was conceivable that the atheist policy of the Soviet government would have a negative effect on ecclesiastical activity, so in September 1944, Miklós Dudás arrived in Uzhgorod and at the meetings held in the three established centers Uzhgorod, Mukachevo and Khust - set the direction the priests had to follow for the preservation of the church. He instructed that everyone should remain in place and that no one should join the retreating Hungarian army - in order for the Greek Catholic churches to continue operating - instructed to preach and strengthen the faith in Catholicism among the local population with even greater zeal, and continue the religious service under all circumstances ${ }^{42}$. He also allowed priests to hold masses outside the church, on the premises of the school, private houses, including abbreviated ceremonies without mass accessories ${ }^{43}$.

After the arrival of the Red Army in Transcarpathia, the clergy of the Greek Catholic Eparchy of Mukachevo did everything in their power to keep the oath they had taken before Bishop Miklós Dudás ${ }^{44}$. With the exception of six people, they did not leave their designated positions.

In 1941 , the population of Transcarpathia was $852,546^{45}$. At the end of the Second World War, the majority of the Transcarpathian population was Greek Catholic ${ }^{46}$, with a total of 461,555 believers, most of whom were of Ruthenian nationality, and also 28,000 Hungarians, 16,000 Romanians, and 3,000 Slovaks ${ }^{47}$. The number of Orthodox people was between 109-121 thousand, 81 thousand were Roman Catholics and 78 thousand were Reformed ${ }^{48}$. The People's Council of

${ }^{40}$ Bendász D. A Munkácsi Görögkatolikus Egyházmegye a szovjet megszállás után és ma. A kommunizmus áldozatai, rehabilitációs alternatívák Kelet-Közép-Európában I Molnár D. E., Molnár D. I. (ed.). Berehove: II. RFKMF Lehoczky Tivadar Társadalomtudományi Kutatóközpont, 2016. Ol. 199.

${ }^{41}$ Hodinka A. A munkácsi görög-katolikus püspökség története. Budapest: Magyar Tudományos Akadémia, 1909. O1. 709.

${ }^{42}$ Transcarpathian Regional State Archives. F. 2558. Op. 1. Ed. hr. 5392. P. 56-58.

${ }^{43}$ Transcarpathian Regional State Archives. F. 2558. Op. 1. Ed. hr. 5392. P. 60-61.

44 Mihály Z., Zombori I. Az egyház hatalma - a hatalom egyháza. Budapest: METEM, 2015. P. 63.

${ }^{45}$ Marosi I. Görögkatolikus Magyarok... Ol. 42.

${ }^{46}$ Transcarpathian Regional State Archives. F. 151. Op. 24. Delo Nr. 802. P. 8.

${ }^{47}$ Botlik J. Hármas kereszt alatt... Ol. 275.

${ }^{48}$ Oficinszkij R. A szovjet időszak... O1. 288. 
Transcarpathian Ukraine did its utmost to steer the denominational relations in the "right" direction, strengthening the Orthodox Church, while condemning the other denominations to annihilation.

In 1943, Stalin restored the Moscow Orthodox Patriarchate, thus deciding the fate of the Greek Catholic Church ${ }^{49}$.

We know from Romzha's report that in the Eparchy of Mukachevo, 306 priests served in 447 churches before the "unification"

As early as 1944, the Soviet invaders began the systematic liquidation of the Greek Catholic Church in Transcarpathia, during which Theodore Romzha himself was the victim of an assassination attempt ${ }^{51}$ at the Mukachevo hospital on November 1, 1947. Although he tried to be loyal to the new power, but, despite the pressure on him, rejected the apostasy and was unwilling to participate in the liquidation of his church ${ }^{52}$.

Uzhgorod was occupied by the Soviet forces on October 28, 1944. The arriving Soviet army and the pro-Soviet local authorities celebrated the anniversary of the Great October Socialist Revolution of 1917 on November 7, 1944, in the building of the Rákóczi Cinema, situated opposite the Roman Catholic Church in Uzhgorod, and the prefectures of the Transcarpathian headquarters also welcomed and celebrated the victory of the Soviet army. The leadership of the Greek Catholic Eparchy of Mukachevo was ordered here for a meeting ${ }^{53}$ and bishop Theodore Romzha was invited to give a solemn speech in which he would have to ask on behalf of the people of Transcarpathia to secede from the Czechoslovak Republic. Bishop Romzha wanted to entrust canon Sandor Chira to give the solemn speech - but since two political commissioners (in the rank of major) had been "staying" at his home by then, it quickly became known - and this was not allowed, on the grounds that the military wanted to hear him specifically, and even offered him that they would write the speech for him, which ${ }^{54}$ Romzha rejected, and eventually gave a short speech. In it, he thanked Heavenly Father for not causing too much damage in Transcarpathia in World War II, thanked

${ }^{49}$ Botlik J. Hármas kereszt alatt... O1. 277.

${ }^{50}$ Transcarpathian Regional State Archives. F. P-1490. Op. 1. Delo Nr. 3. P. 14.

${ }^{51}$ Botlik J. Hármas kereszt alatt... O1. 278-282.

${ }^{52}$ Puskás L. Romzsa Tódor püspök élete és halála. H. n. : Don Bosco Kiadó Bt, 1998. O1. 89-283.

${ }^{53}$ Oficinszkij R. Egyházellenes intézkedések. Kárpátalja 1919-2009 történelem, politika, kultúra / Fedinec Cs., Vehes M. (eds.). Hely nélkül: Argumentum, MTA Etnikainemzeti Kisebbségkutató Intézete, 2010. O1. 289.

${ }^{54}$ Bendász I. Greek Catholic Library and Archives. Chira Sándor hagyatéki iratai. Visszaemlékezés. Karaganda, July 14, 1958. P. 1. (hereinafter: BIGKKL, Chira Memoirs). 
the great leader, Stalin, for his liberation, and wished him success on the road to peace ${ }^{55}$.

The chairman of the meeting, Sergei Stasev, the son of an emigrant Russian lawyer based in Uzhgorod, who had been appointed mayor of Uzhgorod $^{56}$ by the Soviet authorities a few days earlier, read out a short telegram to the President of the Czechoslovak Republic: "The people of Transcarpathia are asking you, Mr. President, to be released from the Republic [... ",57. The following day, a brief (voluminous, according to other sources) news item signed by Romzha appeared in Zakarpatska Pravda, in which the bishop on behalf of the eparchy announced the voluntary accession and reunification of Transcarpathia with Soviet Ukraine, which was published in the Kiev newspapers as well ${ }^{58}$. Romzha refuted the news, and was contacted by the authorities who stated that the published news were the ones that he should have spoken about ${ }^{59}$. After this, the bishop decided that he would no longer attend such events and would not talk the press either.

To the serious threats from political officers of the army, according to which refusing to sign the manifesto was a confrontation with Soviet power, the bishop replied: "The Manifesto is a political document and a bishop must not deal with politics" 60 .

The liquidation of the Greek Catholic Church, which was considered an enemy, was first initiated in Galicia ${ }^{61}$, as there was a total of 5 million believers in the Soviet Union who practically lived in western Ukraine and who provided support for the independence of the Ukrainian state, not recognizing Soviet authority ${ }^{62}$. Shortly after the invasion of the Red Army, Havryl Kostelnik, a great defender of Orthodoxy, organized an

${ }^{55}$ Romzsa Tódor püspök hitvallása és vértanúhalála. Készült Puskás László atya boldoggáavatási életrajzi anyagai nyomán/ Rozália R. Bulecza (ed.). Uzhhorod Budapest: Intermix Kiadó, 2000. P. 27.

${ }^{56}$ Bendász I., Bendász D. Helytállás és tanúságétel. A Munkácsi Görög Katolikus Egyházmegye hitvalló és meghurcolt papjai. Uzhhorod - Budapest: Galéria-Écriture, 1994. O1. 132.

${ }^{57}$ BIGKKL. Chira Memoirs, 2.

${ }^{58}$ BIGKKL. Chira Memoirs, 2.

${ }^{59}$ Oficinszkij R. Egyházellenes intézkedések... Ol. 289.

${ }^{60}$ Romzsa Tódor püspök... P. 27.

${ }^{61}$ Gönczi A. A görögkatolikus egyház felszámolása. Kárpátalján az Orosz Föderáció Állami Levéltára anyagainak tükrében. Értékek és kihívások / Gazdag V., Karmacsi Z., Tóth E. (eds.). II. kötet. Uzhhorod: Autdor - Shark, 2016. O1. 41-48.

${ }^{62}$ Botlik J. Hármas kereszt alatt... O1. 277. 
initiative group whose task was to "reunite" the Greek Catholic Church in Galicia with the Russian Orthodox Church ${ }^{63}$.

On November 18, 1944, in Mukachevo, the leaders of the Mukachevo-Prešov Orthodox Eparchy - deputy bishop, abbot Feofan Szabó, archabbot Oleksiy Kabaljuk, Ivan Kopolovych, secretary of the episcopal office, dean Dmitry Belyakov, and Petro Lintur, a grammar school teacher from Khust compiled a letter asking the leader of the Soviet Union to annex Transcarpathian Ukraine to the Union of Soviet Socialist Republics as the "Carpathian Soviet Republic", whose borders would extend from Yasinia to Poprad, from the river Uzh to Debrecen. They also requested that the Mukachevo-Prešov Orthodox Eparchy be placed under the authority of the Moscow Patriarchate, and that Greek Catholic churches, other ecclesiastical property and land of Transcarpathian Ukraine be given to the Orthodox church. After the letter was signed by 23 priests as well, with the support of the political department of the 4th Ukrainian Front, on December 7, 1944, the Orthodox delegation took the letter to Moscow ${ }^{64}$. Of course, what was requested in the letter was soon fulfilled and as early as the end of 1944 the eparchy was annexed to the Moscow Patriarchate, and the properties of the Greek Catholic Church were given to the Orthodox Church ${ }^{65}$. Thus, the Soviet leadership wanted to liquidate the Greek Catholic Church using the method of "reunification" 66 .

The Church General Assembly was held in March 1946 in Lviv, according to a scenario developed by the State Security Service. Father Havryl Kostelnik fulfilled his obligations completely. He gave a speech on "the need for the Greek Catholic Church to be reunited with the Russian Orthodox Church". Greek Catholic bishops were not present at the event, as they were imprisoned from April 1945 for their opposition, on charges of collaborating with the Hitlerites. However, in order to make a decision in accordance with ecclesiastical customs, the "reunification" was consecrated by the four Orthodox bishops. Subsequently, the resolutions of the "Greek Catholic Ecclesiastical

${ }^{63}$ Puskás L. Gondolatok az orosz ortodox egyház 20. századi történetéből. Lapszéli jegyzetek az Orosz Ortodox Egyház története első magyar nyelvű kiadásához. Teológiai Hittudományi Folyóirat. № 34. Évfolyam, 3-4. Szám, 2000. Ol. 130.

${ }^{64}$ Oficinszkij R. A szovjet időszak... O1. 290.

${ }^{65}$ Transcarpathian Regional State Archives. F. P-14. Op. 1. Szpr. 666. P. 1-123; Botlik J. Hármas kereszt alatt... Ol. 277.

${ }^{66}$ Brenzovics L. Az Ukrán Szovjet Szocialista Köztársaság Kárpátontúli területe, 1945. június - 1991. augusztus. Kárpátalja. MTA Regionális Kutatások Központja / Baranyi Béla (ed.). Pécs - Budapest : Dialóg Campus Kiadó, 2009. Ol. 100. 
Assembly held in Lviv on March 8-10, 1946", i. e. the Council of Lviv $^{67}$, which repealed the Decree of the Brest Union of 1596 on ecclesiastical union, were published. With this, the church seceded from the jurisdiction of the Vatican and merged with the Russian Orthodox Church $^{68}$. After that, the Greek Catholic Eparchy of Mukachevo remained the only functioning eparchy in the Soviet Union. It was obvious that its abolition was only a matter of time for the authorities.

The same scenario was intended to be applied in Transcarpathia, but the circumstances here did not allow it, as the region was bordered by several countries, so there was a risk of a possible international conflict. In addition, not only ecclesiastical but also familial relations united the population with the Roman Catholic Church, which was notoriously averse to both the Communists and the Orthodox church. Therefore, the representatives of the Soviet authorities carried out the liquidation of the Greek Catholic Eparchy of Mukachevo gradually ${ }^{69}$, for which, among other things, they began to look for tangible, anti-Soviet accusations in the episcopal library; they increased terror, psychological pressure on the bishop, the priests, and so on ${ }^{70}$.

Bishop Romzha, still a young man, as the leader of the Eparchy of Mukachevo had never been involved in political life, so the Soviet leadership could not bring any charges against him that might have put him and thus the Greek Catholic Church in suspicion. Nevertheless, the Soviet power wanted to force the bishop down on his knees in every way. However, the chief pastor stubbornly resisted the will of the Soviets, according to which the bishop should have initiated a unification with the Moscow Orthodox Church ${ }^{71}$.

When the Soviets invaded Transcarpathia on October 27, 1944, Bishop Romzha chose Sandor Chira as his vicar, on whose experience, advice, insight, diplomatic sense he could lay on and who was his true comrade-in-arms against the attacks of the Stalinist state power.

Sandor Chira was born on January 17, 1897 in the village of Irhóc (Vilkhivtsi) in Maramures County, the son of Kornél Chira, a Greek Catholic dean-pastor and Berta Tabakovics. During the first two years of elementary school, he studied in Nyéresháza (Neresnytsia), the 3rd and

${ }^{67}$ Riskó M. Az eskü mindvégig kötelez. A kárpátaljai görög katolikus egyház kálváriája 1944-1991. Uzhhorod - Budapest: Intermix Kiadó, 1995. O1. 14; Oficinszkij R. A szovjet időszak... Ol. 294.

${ }^{68}$ Gönczi A. A görögkatolikus egyház... Ol. 41.

${ }^{69}$ Gönczi A. A görögkatolikus egyház... Ol. 42.

${ }^{70}$ Romzsa Tódor püspök... P. 35.

${ }^{71}$ Bendász D. A Munkácsi Görögkatolikus... Ol. 199. 
4th grade in Vilkhivtsi in a Ruthenian cshool, and he completed his grammar school studies at the Hungarian royal Catholic (Piarist) grammar school in Máramarossziget (Sighetu Marmației). From 1915, he studied at the Faculty of Theology of the Pázmány Péter University in Budapest. After this, on December 19, 1920, Antal Papp of the Eparchy of Mukachevo ordained him. From 1920 to 1922, he was an eparchy registrar and archivist. From 1922 to 1923, he was a temporary administrator in Vilkhivtsi, then from 1923 to 1924 in Kökényes (Ternovo, Maramures county) he served as a chaplain for the parochus Elek Gorzó ${ }^{72}$. In 1924-1932, he served as a spiritual of the priest seminary in Uzhhorod, and as a theology teacher in 1924-1946 ${ }^{73}$, until 1949 according to other data ${ }^{74}$. Péter Gebé, the bishop of the eparchy of Mukachevo, appointed him professor of church history and canon law ${ }^{75}$, and from time to time he also taught law, church history, pastoral and moral lectures. In 1924, he became an adviser to the eparchy court ${ }^{76}$ and a member of the Christian People's Party ${ }^{77}$. From 1925 to 1927 , he was president of the Transcarpathian St. Josaphat Missionary Society ${ }^{78}$. From 1 December 1928, he was pastor of the Uzhhorod City Hospital. ${ }^{79} \mathrm{He}$ was a canon in 1932-1944 (he used this title until his death to disguise his status as a bishop). In 1930, he was elected an adviser to the Episcopal Consistory, and was awarded the title of Pontifical Chaplain by the Holy See ${ }^{80}$. From 1934 to 1939 , he was Rector Seminarii, i. e. the rector of the Greek Catholic seminary in Uzhhorod ${ }^{81}$. Bishop Sándor Sztojka dismissed him from his position as rector on July 17, 1939, but confirmed him as a theology teacher and member of the eparchy court ${ }^{82}$, and later he was appointed president of the eparchy court ${ }^{83}$. From 1943, he was appointed papal prelate by Pope Pius XII ${ }^{84}$.

\footnotetext{
${ }^{72}$ Bendász I., Bendász D. Helytállás és tanúságétel... O1. 24, 124.

${ }^{73}$ Transcarpathian Regional State Archives. F. 2558. Op. 1. Ed. hr. 5392. P. 88.

${ }^{74}$ Bendász I., Bendász D. Helytállás és tanúságétel... Ol. 124.

${ }^{75}$ Transcarpathian Regional State Archives. F. 151. Op. 13. Delo Nr. 1511. P. 111.

${ }^{76}$ Transcarpathian Regional State Archives. F. 151. Op. 13. Delo Nr. 1511. P. 111.

${ }^{77}$ Transcarpathian Regional State Archives. F. 2558. Op. 1. Ed. hr. 5392. P. 19.

${ }^{78}$ Transcarpathian Regional State Archives. F. 2558. Op. 1. Ed. hr. 5392. P. 48.

${ }^{79}$ Transcarpathian Regional State Archives. F. 151. Op. 13. Delo Nr. 1511. P. 111.

${ }^{80}$ Riskó M. «A jó harcot megharcoltam, a hitet megöriztem...». Betekintés Chira Sándor püspök életútjába a források tanúságával». Acta Academiae Beregsasiensis / Orosz I., Szikura J. P. II. Berehove - Uzhhorod : RFKMF, 2014. 13 évf. 1. k., Ol. 168.

${ }^{81}$ Transcarpathian Regional State Archives. F. 2558. Op. 1. Ed. hr. 5392. P. 52.

${ }^{82}$ Transcarpathian Regional State Archives. F. 151. Op. 18. Ed. hr. 1715. P. 2.

83 Transcarpathian Regional State Archives. F. 2558. Op. 1. Ed. hr. 5392. P. 52.

${ }^{84}$ Botlik J. Hármas kereszt alatt... Ol. 286.
} 
The exact time of the consecration of Sandor Chira as bishop is still unclear. Some say that as early as September 14, 1944, Bishop Miklós Dudás, the administrator of the eparchy of Mukachevo with the help of István Madarász, the Roman Catholic bishop of Košice, ordained him a bishop at the same time as dr. Theodore Romzha. Although this is doubtful, since in this case the consecration would not have been a secret ${ }^{85}$. Others claim that Romzha secretly consecrated him in 1944 with the permission of the Holy See ${ }^{86}$. According to some sources, the secret consecration took place on December $30,1945^{87}$. And finally, according to some estimations it was done in 1947, after the death of Bishop Romzha ${ }^{88}$.

In the second half of January 1945, Colonel Tiulpanov, who had become a frequent visitor to the Episcopal Palace because he lived across the street, in the requisitioned building that belonged to the lawyer Dr. Eperjessy, ordered Bishop Romzha to pay a visit to General Ivan Petrov, 4th Ukrainian Front commander at the Michalovce headquarters, as the commander-in-chief of the army liberating Uzhhorod, and reprimanded the leader of the Greek Catholic Eparchy of Mukachevo for failing to do so by himself ${ }^{89}$. Petrov and General Lev Mehlis received the bishop and canon Chira together. The topic of the meeting was the accession of Transcarpathia to Soviet Ukraine, amid harsh intimidation. Both church figures expressed the view that "the governments of the two countries, CSR and USSR, are the ones to deal with the issue of accession" $"$. Seeing the anger of the generals, Chira tried to remedy the situation by greeting them with words of appreciation he learned from the newspapers, thus saving the bishop ${ }^{91}$.

In February 1945, father Péter Demjanovics, the Greek Catholic parochus of Rakhiv, who was a member of the Upper House of the Parliament representing Transcarpathia between 1933 and 1944 during Hungarian rule, was arrested. He was accused of espionage and betrayal of the "Soviet people". The extraordinary court sentenced him to death. The elderly, sick man was shot dead on his hospital bed at the Uzhhorod hospital on Good Friday, April 21, $1945^{92}$.

\footnotetext{
${ }^{85}$ Botlik J. Hármas kereszt alatt... O1. 283.

${ }^{86}$ Bendász I., Bendász D. Helytállás és tanúságétel... O1. 124.

${ }^{87}$ Riskó M. «A jó harcot megharcoltam, a hitet megöriztem...»... Ol. 170.

${ }^{88}$ Bendász I., Bendász D. Helytállás és tanúságétel... O1. 128-129.

${ }^{89}$ BIGKKL. Chira Memoirs, 3.

${ }^{90}$ BIGKKL. Chira Memoirs, 4.

${ }^{91}$ BIGKKL. Chira Memoirs, 4.

${ }^{92}$ Botlik J. Hármas kereszt alatt... Ol. 284.
} 
Soviet policy sought to destroy the Greek Catholic Church according to a well-thought-out, pre-designed scenario. The exact steps of the scenario were requested by Moscow from Uzhhorod on January 16, 1947, by S. N. Liamshin-Agafonov, the Transcarpathian religious commissioner of the USSR ${ }^{93}$. Vilyhovy strongly demanded from Moscow that Romzha and his adviser Chira be kept under constant surveillance, because they had a great influence on believers, priests, who do exactly what they are instructed to do. He also called on Turjanica to take stronger action in connection with the secession from the Vatican and to ensure that local parishioners do not come into contact with foreign Greek Catholics in any way, especially those from Prešov and Romania ${ }^{94}$.

On March 24, 1945, the People's Council issued a decree entitled "On the Free Choice of Religion", , according to which all adult citizens had the right to change their religion of their own free will or to be nondenominational, and minors could change their religion with the consent of their parents or guardians ${ }^{96}$.

On March 24, 1945, the People's Council of Transcarpathian Ukraine passed a decree banning the use of the term "Greek-Eastern" and instead ordered "Pravoslavnyi" (the Russian term for "Orthodox" literally meaning "the right, proper glorification") ${ }^{97}$.

On April 20, 1945, the Greek-Eastern Eparchy of Mukachevo-Prešov was annexed to the Moscow Patriarchate. During the Soviet period, the Orthodox Church grew, and soon most of the believers, churches, priests who had already been trained in Soviet priest seminaries belonged to this church. The financial support withdrawn from the Greek Catholic church was given to the Orthodox as well ${ }^{98}$. The official name of the church was "Русская" (Russkaya), meaning Russian Orthodox Church, but in the Ukrainian language the term "Руська" (Rus'ka, ancient Ukrainian), reminiscent of the time of Kievan Rus (Kyivs'ka Rus') was used to deceive the believers ${ }^{99}$.

93 Transcarpathian Regional State Archives. F. P-1490. Op. 1. Delo Nr. 2. P. 3.

${ }^{94}$ Transcarpathian Regional State Archives. F. P-1490. Op. 1. Delo Nr. 2. P. 2.

${ }^{95}$ Transcarpathian Regional State Archives. F. P-1490. Op. 1. Delo Nr. 2. P. 1-2.

${ }^{96}$ Transcarpathian Regional State Archives. F. P-14. Op. 1. Szpr. 660. P. 1-5.

${ }^{97}$ Transcarpathian Regional State Archives. F. P-14. Op. 1. Szpr. 661. P. 1-4.

${ }^{98}$ Transcarpathian Regional State Archives. F. P-14. Op. 1. Od. zb. 665. P. 1-22.

99 Oficinszkij R. Megtürt pravoszlávok és üldözött reformátusok. Kárpátalja 1919-2009 történelem, politika, kultúra / Fedinec Cs., Vehes M. (eds.). Hely nélkül: Argumentum, MTA Etnikai-nemzeti Kisebbségkutató Intézete, 2010. O1. 296. 
Meanwhile, Greek Catholic priests were being arrested on charges of cooperating with the «Hungarian fascist system» ${ }^{100}$. Numerous antichurch publications disguised as scientific appeared with the aim of substantiating the need to abolish the Greek Catholic denomination, undermining the authority of the church and priests, ecclesiastical leaders were accused of betraying the people, cooperating with oppressive, occupying powers, including the Nazis. The terms "Enemies of the people", "counter-revolutionaries", "fascists", "anti-Soviet", "disruptive", and similar adjectives were used to describe them.

An agent file was opened on the leaders of the eparchy, marked "cross-bearers". They kept a continuous record of them, collected "compromising" information, and reported on them ${ }^{101}$.

According to the decision of the People's Council of August 29, 1945, the episcopal archives and libraries of the Eparchy of Mukachevo were inspected $^{102}$ and documents that were "against the system" were destroyed, and the rest were handed over to the Central State Historical Archives, founded in January 1945, which already had its headquarters in Uzhhorod and a branch in Berehove ${ }^{103}$.

The Soviet authorities increasingly urged Greek Catholic parishes to convert to the Orthodox faith ${ }^{104}$. They succeeded in part, but a significant proportion of the believers became Roman Catholic instead ${ }^{105}$. Others secretly exercised their faith between 1949 and 1989, operating in illegality as a catacomb church ${ }^{106}$.

On August 21, 1946, according to the decision of the Transcarpathian Regional Council of People's Deputies, the legal nationalization of the church and monastery lands began ${ }^{107}$. Bishop Romzha defended the interests of the eparchy as long as possible, resolutely resisted the

${ }^{100}$ Oficinszkij R. Egyházellenes intézkedések... P. 291.

${ }^{101}$ Oficinszkij R. Szekularizáció szovjet módra. Kárpátalja 1919-2009 történelem, politika, kultúra / Fedinec Cs., Vehes M. (eds.). Hely nélkül: Argumentum, MTA Etnikainemzeti Kisebbségkutató Intézete, 2010. Ol. 289.

${ }^{102}$ Transcarpathian Regional State Archives. F. P-14. Op.1. Szpr. 667. P. 1.

${ }^{103}$ Transcarpathian Regional State Archives. F. P-14. Op. 1. Od. zb. 702. P. 1-9.

${ }^{104}$ Bendász I. Öt év szögesdrót mögött. Egy kárpátaljai görög katolikus pap naplója a Gulágon. Uzhhorod: Harmadik bővített kiadás, 2012. Ol. 4.

${ }^{105}$ Az elitélt és kivégzett görögkatolikus papokról összegyüjtött adattár. Kárpátaljai Magyar Gulág-lexikon / Dupka (ed.). Uzhhorod - Budapest: Intermix Kiadó, 1999; Szabó, G., father. Tövises út az egységhez. Fejezetek a kárpátaljai görög katolikus egyház történetéböl. Uzhhorod - Budapest : Intermix Kiadó, 1999. Ol. 73.

${ }^{106}$ Bendász D. A Munkácsi Görögkatolikus... O1. 202.

${ }^{107}$ Kárpátalja évszámokban 1867-2010 / Vehes M. et al. (ed.). Uzhhorod: Hoverla, 2011. O1. 138. 
Orthodox conversion, fought against the incorporation into the Moscow Patriarchate, constantly appealed to the Soviet leadership to overrule the measures against the Greek Catholic Church, to get an answer to the question what laws and pragraphs were being applied against the Greek Catholic denomination and in what codes could those be found. "We want to know these laws on which you act so that we can study them and learn as much as possible to meet their expectations. Therefore, with great respect, please help us obtain these codes, decrees, or give us advice on where to obtain them "108. He visited the settlements one by one, encouraged the priests and the faithful to persevere. He asked the authorities to allow the free practice of religion ${ }^{109}$ in accordance with the Constitution of the Soviet Union and the operation of the Theological Academy, where only church education took place ${ }^{110}$. He refused to send a report on the ethnicity of the Greek Catholic priests: "We do not keep a register of ethnicity" "111. He resolutely opposed the violent Greek Catholic church occupations by Orthodox believers: "In Ódávidháza (Stare Davydkovo), on the night of July 5 to 6, 1947, the Orthodox believers brutally, like terrorists, invaded our Greek Catholic church, broke down the door and took possession of it, even though they have their own Orthodox church in the village. The number of Greek Catholic believers in Ódávidháza is 541, while the number of Orthodox believers is only 77. [...] Please intervene in order to return our church",112. "There are 1,043 Greek Catholics and 124 Orthodox believers living in Bábaku't (Babychi). On the night of July 19-20, 1947, in a barbaric, unconstitutional manner, in violation of religious freedom, Orthodox believers broke into the Greek Catholic Church and occupied it, thus humiliating the Soviet State" ${ }^{\text {,13 }}$. He kept speaking up against the eviction of priests ${ }^{114}$. Together with the Reformed and Roman Catholic church leaders, he asked not to desecrate or take away the cemeteries because it was contrary to the "regulations of the Stalinist Constitution"" these reasons, it was forbidden for the bishop to travel outside the territory of Uzhhorod without special permission. Due to his resistance to

\footnotetext{
${ }^{108}$ Transcarpathian Regional State Archives. F. P-1490. Op. 1. Delo Nr. 17. P. 7.

${ }^{109}$ Transcarpathian Regional State Archives. F. P-1490. Op. 1. Delo Nr. 3. P. 8.

110 Transcarpathian Regional State Archives. F. P-1490. Op. 1. Delo Nr. 3. P. 1;

Transcarpathian Regional State Archives. F. P-1490. Op. 1. Delo Nr. 16. P. 6.

${ }^{111}$ Transcarpathian Regional State Archives. F. P-1490. Op. 1. Delo Nr. 17. P. 3.

112 Transcarpathian Regional State Archives. F. P-1490. Op. 1. Delo Nr. 17. P. 8.

${ }^{113}$ Transcarpathian Regional State Archives. F. P-1490. Op. 1. Delo Nr. 17. P. 10.

${ }^{114}$ Transcarpathian Regional State Archives. F. P-1490. Op. 1. Delo Nr. 17. P. 12.

${ }^{115}$ Transcarpathian Regional State Archives. F. P-1490. Op. 1. Delo Nr. 24. P. 6.
} 
the attempt of merge and his influence on the parishioners, the Soviet authorities considered him the main obstacle of the liquidation of the Unitus Church, as Romzha's resistance led to action against the entire church $^{116}$.

Greek Catholic clergy tried to resist the merge, encouraging the people as well ${ }^{117}$. If it turned out, it was considered agitation. Written reports among the archival document include "the dangers of Greek Catholic agitation, the role of the Greek Catholic clergy during the Hungarian occupation" "18, and the "anti-people speeches of Greek Catholics at the time of the transition of Greek Catholic churches to the Orthodox Church",119.

In August 1946, a military car arrived at the Káptlan Street apartment of canon Chira and his former priest student named Tivadar forced him into the car with an automatic weapon on his shoulder and then covered him with a cloak so that he would not be recognized. However, women from the neighborhood recognized him and soon spread the word that Chira was taken to the headquarters of SMERSH, the most dangerous antispy detachment called Death to Spies, i. e. to Ajvazov Street ${ }^{120}$. Here he was questioned for several hours about the connection of the episcopal office with the Vatican and Rome. The canon was instructed to enter their spy service and report to them on August 10th. But he didn't do so ${ }^{121}$.

As one of the next steps, the seminary building, the historic Alma Mater, was taken away by the Soviet authorities and had to be "temporarily" handed over to the military. The castle was emptied in a short time and the local newspapers wrote that the museum of Transcarpathia would be opened in the castle. The three-member "commission" ordered the little priests, the last priest students of the eparchy, from the Alumneum and the Convent to the Episcopal Palace. Canon Chira was also instructed to move, but the canon, claiming that he lived in the apartment with his mother, remained there until his arrest ${ }^{122}$.

In the spring of 1946, I. Turianytsia, President of the People's Council of Transcarpathian Ukraine, asked for canon Chira. It was clear

\footnotetext{
${ }^{116}$ Botlik J. Hármas kereszt alatt... Ol. 283.

${ }^{117}$ Pekar A. B. "Tanúim lesztek». Adalékok a kárpátaljai görög katolikus egyház vértanúságához. Miskolc: Felsőmagyarország Kiadó, 2003. Ol. 13-16.

${ }^{118}$ Transcarpathian Regional State Archives. F. P-14. Op. 1. Szpr. 662. P. 1-11.

${ }^{119}$ Transcarpathian Regional State Archives. F. P-14. Op. 1. Szpr. 663. P. 1-2.

${ }^{120}$ BIGKKL. Chira Memoirs, 5; Bendász I., Bendász D. Helytállás és tanúságétel...

${ }^{121}$ BIGKKL. Chira Memoirs, 4-5.

${ }^{122}$ BIGKKL. Chira Memoirs, 6.
} Ol. 134. 
that the meeting on the «important matter» was going to be an urge to convert to the Orthodox faith. At the beginning of the meeting, even before Turjanica began to speak, Chira noted that although he was familiar with "the many moral and political issues of the church from the papal throne all the way to the smallest monastic cell or chaplain's room [...], but nothing can lure me away from the Holiness of the Pope, from my Catholic faith, from my fidelity to my church, neither prison of any kind, nor torture, not even death [...]. I will not descend from horseback to donkey back and I will not accept your offer under any circumstances [...]". Turjanica replied, "I wanted what is good for you. You will see the consequences. I'm sorry for you!","23.

In May 1947, the Uzhhorod Theological Academy was deprived of all educational equipment ${ }^{124}$. Soon the seat of the eparchy, the cathedral, the Episcopal Palace, the Theological Academy, the eparchy priest school, the cantor teacher training school, the teacher training institute, the girls' high school, the boarding schools, the teacher training boarding school, the girls' boarding school, the Erzsébet House, the Khust boarding school, the Mukachevo boarding school, the Holy Family Orphanage, the Khust orphanage ${ }^{125}$, the Basilite monastery on the Chernecha Mountain, the printing house and all other Greek Catholic property were handed over to the Orthodox Church. With this, all the educational institutions of the eparchy were confiscated ${ }^{126}$.

Publications on the Greek Catholic Church were banned in the press, and all functioning Greek Catholic advocacy or charitable and scientific organizations were liquidated.

The Soviet authorities tried hard to intimidate canon Chira, the second most prominent figure in the eparchy. On the church feast vigil of August 27, the Galician apostate, Dr. Kostelnik, a former Greek Catholic doctor of theology, teacher, a delegate of the Soviet authorities, visited Chira to convince him of the usefulness and necessity of the transition to Orthodoxy. His attempt was again unsuccessful, so neither Romzha nor Chira could attend the traditional Assumption Day mass on August 28, but Vilkhovyi himself traveled to Mukachevo. Dr. Kostelnik preached against Rome and former Greek Catholic apostate candidates who had

${ }^{123}$ BIGKKL. Chira Memoirs, 7.

${ }^{124}$ Bendász D. A Munkácsi Görögkatolikus... O1. 202.

${ }^{125}$ Transcarpathian Regional State Archives. F. P-1490. Op. 1. Delo Nr. 16. P. 2-3; valamint Bendász D. A Munkácsi Görögkatolikus... Ol. 199.

${ }^{126}$ BIGKKL. Chira Memoirs, 7. 
converted to the Orthodox faith were also present, namely Istvan Danielovics and Gyula Kossey ${ }^{127}$.

According to a resolution of the Transcarpathian Regional Committee of the Communist Party of Ukraine accepted in March 1947, a "group for the reunification of the Greek Catholic Church and the Russian Orthodox Church" was set up in accordance with the "Galician scenario", 28 .

In December 1948, Rasput'ko, the head of the Uzhhorod branch of the Ministry of Cults, ordered the vicar Miklos Muranyi, canon Sandor Chira and pastor Janos Szemedi. The seriousness of the situation is indicated by the presence of Vilkhovyi himself, who informs them that the Greek Catholic clergy in Galicia had solemnly adopted the Orthodox religion and stressed that they had been waiting for them to do so for two years, and that he cannot register the Greek Catholic eparchy. The 3 invitees stated that they would rather choose hard labour to make a living. In the same month, Vilkhovyi summoned all Greek Catholic priests and informed them that unitarians would not be registered ${ }^{129}$.

By the end of 1948, 35 Greek Catholic pastors had been victims of religious persecution, sentenced on various fabricated charges to 5,10 , 25 years of forced labor, confiscation of property, and 33 parochuses had left Transcarpathia illegally ${ }^{130}$.

On January 26, 1949, the cruel pressure on the priesthood brought its first result, when the first Greek Catholic priest gave in to Soviet pressure and apostatized ${ }^{131}$.

On January 26, 1949, by order issued almost simultaneously, five urban Greek Catholic priests were arrested and immediately instructed to convert $^{132}$. Only the parochus of Nagyszőlős (Vynohradiv), Pal Karcub, was not arrested, although he most resolutely refused apostasy, but the authorities did not dare to publicly deport him from his 16 children and his wife, who was repeatedly declared a «hero mother» by the state ${ }^{133}$.

${ }^{127}$ BIGKKL. Chira Memoirs, 8.

128 Oficinszkij R. A görög katolikus püspökség felszámolása. Kárpátalja 19192009 történelem, politika, kultúra / Fedinec Cs., Vehes M. (eds.). Hely nélkül: Argumentum, MTA Etnikai-nemzeti Kisebbségkutató Intézete, 2010. O1. 294.

${ }^{129}$ Botlik J. Hármas kereszt alatt... Ol. 285; BIGKKL. Chira, Memoirs, 18.

${ }^{130}$ Botlik J. Hármas kereszt alatt... O1. 284-285.

${ }^{131}$ Dupka G. Koncepciós perek magyar elitéltjei... Ol. 48.

${ }^{132}$ The chaplain of the Uzhhorod Cathedral, Laszlo Puskas, Dumiskovics Eumen from Mukachevo, Jozsef Kampo from Berehove, Miklos Ruszinko and dr. Demeter Popovics from Khust, who became the first victims of the now public persecution of the Catholic Church (Bendász I. Öt év szögesdrót mögött... Ol. 50).

${ }^{133}$ Bendász I. Öt év szögesdrót mögött... Ol. 51. 
On February 12, 1949, the Ministry of State Security of the Ukrainian SSR sent a letter to the authorities requiring the immediate liquidation of the Greek Catholic Church in Transcarpathia.

On February 16, 1949, the local authorities and the MGB (Ministry of State Security) stormed the eparchy building and the chairman of the executive committee of the regional council, Sergei Stasev, and Nazarenko, the secretary of the board, called Miklos Muranyi, the head of the office of the Mukachevo eparchy, to hand over the cathedral and other buildings to the Orthodox Church. In addition, they forced Miklos Muranyi's chapter vicar to edit a so-called dissolution decree ${ }^{134}$, which was later distributed to all Greek Catholic priests. The following day, 17 February, 13 members of the Uzhhorod executive branch returned to the eparchy with military escort to take over the cathedral and residence, along with its library and archives, offices and suites, i. e. the Greek Catholic Cathedral, the bishop's palace and everything in it was placed under the supervision of the Orthodox bishop ${ }^{135}$. Thus, on February 17, 1949, the Soviet authorities officially banned the Greek Catholic religion, including its public functioning ${ }^{136}$.

On February 18, 1949, all Greek Catholic parishes in Transcarpathia were notified of the liquidation of the Mukachevo Eparchy. The notice was distributed on bishop's letter paper signed by Miklos Muranyi, who also informed the people that he was resigning from the office of deputy bishop. After reading the letter, some Greek Catholic priests voluntarily converted to the Orthodox faith.

In 1946 and 1949, the Greek Catholics of Galicia and Transcarpathia both «returned» to Orthodoxy, thus invalidating ${ }^{137}$ the Brest ${ }^{138}$ (1596) and the Uzhhorod ${ }^{139}$ (1646) unions.

Because Murányi refused to apostasize, he was arrested on June 24, 1949 , taken to the Korolenko street jail in Kiev, and then transported to the Gulag on September 29, $1951^{140}$.

${ }^{134}$ Botlik J. Hármas kereszt alatt... Ol. 286.

${ }^{135}$ Oficinszkij R. A görög katolikus püspökség... Ol. 75-76.

136 Botlik J. Hármas kereszt alatt... O1. 286-287; Ortutay E. A Kárpátaljai görögkatolikus egyházról. Hatodik Síp, 1990. Június. O1. 20.

${ }^{137}$ Puskás L. Gondolatok az orosz... Ol. 142.

${ }^{138}$ Szantner V. A Hajdúdorogi Egyházmegye története a kezdetektől 1920-ig. Eötvös Loránd Tudományegyetem Bölcsészettudományi Kar, Történettudományi Doktori Iskola. D. n. 10 .

139 Bendász I. Részletek a Munkácsi Görög Katolikus Egyházmegye történetiböl. Uzhhorod: CLIO, KMKSZ, 1999. Ol. 118.

${ }^{140}$ Botlik J. Hármas kereszt alatt... O1. 287. 
In 1949, after the liquidation of the Greek Catholic Eparchy of Mukachevo and the Greek Catholic Church, 40\% of the eparchy's priests, i.e. 132 people, signed their accession to the Orthodox Church ${ }^{141}$. According to other researchers, $47 \%$, or 128 priests, converted to the Orthodox religion $^{142}$. 175 people persevered, insisted on their faith, refused apostasy, and 129 of them (128, according to other researchers ${ }^{143}$ ) were taken to the GULAG - Abes, Inta (Komi-land), Churbay-Nuran, Dzhezgazgan-Rudnik, Spask, Ekibastuz, Karaganda, Tajset (Camp No. 51) (Kazakhstan), Javas, Potyma (Mordovia), Omsk, Vorkuta - to forced labor after the trial in the People's Court. Thirty of them died in the Gulag ${ }^{144} .18 \%$ of the priesthood, i. e. 50 priests, were retired, elderly, their activity was banned ${ }^{145}$.

The liquidation of the Greek Catholic Church in Transcarpathia was completed in the summer of 1952. The last to be detained (July 5, 1952) was the Greek Catholic priest Laszlo Pochil (1910-1983) ${ }^{146}$, and the last to convert to the Orthodox religion on June 27, 1952 was father Vladimir Stripsky, 87.

Sandor Chira, the 52-year-old canon, was arrested on February 10, 1949, around 9-10 p. m. His arrest was made by Lieutenant Colonel Chernetsky ${ }^{147}$. According to the arrest warrant:

"During the Czech regime and the nationalist Voloshin "government", Chira was one of the leaders of the Christian People's Party, who carried out anti-Soviet, fascist activities between 1939 and 1940, encouraged the religious population of Transcarpathia to actively cooperate with Hungarian-fascist occupiers in the fight against the Soviet Union.

Maintaining contact with the Vatican, Chira, as an active missionary of Catholicism, during the Czech regime and the Hungarian occupation in Transcarpathia Ukraine held systematic sermons with anti-Soviet and anti-communist content, cooperated with Catholic newspapers, and informed the Vatican about his activities.

141 Бендас С., Бендас Д. Священики-мученики, сповідники вірності. Ужгород: Закарпаття, 1999. С. 397-402.

${ }^{142}$ Botlik J. Hármas kereszt alatt... O1. 275-276.

${ }^{143}$ Oficinszkij R. A görög katolikus püspökség... Ol. 295.

${ }^{144}$ Botlik J. Egestas Subcarpathica... Ol. 286.

${ }^{145}$ Botlik J. Hármas kereszt alatt... O1. 275-276.

${ }^{146}$ Bendász D. A Munkácsi Görögkatolikus... O1. 202.

${ }^{147}$ Transcarpathian Regional State Archives. F. 2558. Op. 1. Ed. hr. 5392. P. 5. 
In 1938, Chira was awarded the honorary title of Prelate-Canon by the Pope for his active missionary, anti-Soviet, and anti-communist activities.

As one of the leaders and the spiritual leader of the Greek Catholic Church in Transcarpathia, he is actively working to strengthen Catholicism and spread hostile ideas against the Soviet Union in churches, and he conducts anti-Soviet sermons in front of the congregation, in which he spreads provocative, defamatory ideas.

As the Vatican's agent, Chira, in his anti-Soviet activities, expected the imperialist countries to interfere in the internal affairs of the Soviet Union, so he sent defamatory information about the situation in Transcarpathia to the Vatican and representatives of the imperialist states ${ }^{148}$.

After the indictment was filed, an all-encompassing house search was conducted, a number of items were seized, e. g. 1 old iron bed, a small sofa and cabinet, 3 old mattresses and pillows, 2 brown Viennese chairs, a bookshelf, 4 velvet-covered armchairs, 3 paintings, 34 plates, 1 Everight, four-lamp radio, 2 used cassocks and silk cloaks, 3 epitrahils, 11 books. What was not seized was "sealed"

After several hours of comprehensive house search, "the canon found himself in the prison of state security in Uzhhorod" ${ }^{, 150}$.

After months of exhausting, defamatory, humiliating interrogations which began mainly at 11-12 p. m. and ended at 4-5 p.m., and took place at the Uzhhorod jail of the NKVD (February 12-14, 1949), and then at the Kyev Internal Affairs jail of the Ministry of State Security (February 16, 1949, August 6, 1949) - he was sentenced to 25 years in a labour camp.

During the interrogation, investigators asked questions as: What papal encyclicals do you know? Have you ever been to the Vatican? What did you talk to the pope about? What does it mean to be a papal prelate? Why did you get the prelature? Where is your appointment document? Did you agitated against the Soviet Union in Mukachevo when you said in your sermon on Mount Chernecha "Beware of wolves hiding in sheep's clothing?". What was the program of the Christian People's Party during the Czechoslovak occupation? For a few nights, the debate was over why he had not signed the "Manifestum" declaring

\footnotetext{
${ }^{148}$ Transcarpathian Regional State Archives. F. 2558. Op. 1., Ed. hr. 5392. P. 3-4.

149 Transcarpathian Regional State Archives. F. 2558. Op. 1., Ed. hr. 5392. P. 7-12; valamint Transcarpathian Regional State Archives. F. 2558. Op. 1. Ed. hr. 5393. P. 1-20.

${ }^{150}$ BIGKKL. Chira Memoirs, 18.
} 
secession from the Czechoslovak Republic ${ }^{151}$. Where did you get your church degree? What is your pastoral rank and position? Who awarded it? Did you personally travel to the Vatican in 1943 accept the pastoral appointment? ${ }^{152}$ When did you start doing political activity? Under whose influence did you start politicizing ${ }^{153}$ ? What function does the chaplan perform? etc. ${ }^{154}$

During interrogations led by Lieutenant Colonel Aksenov, he admitted that he belonged to the Ukrainian orientation between the two world wars, so the Hungarian leadership interrogated him in 1938, observed him ${ }^{155}$ until 1942 and put him under house arrest for a day ${ }^{156}$ on charges of Ukrainian nationalism. Also, he admitted that he had been to the Vatican in 1933 and $1936^{157}$. He admitted that he had also met the Hungarian leaders - Pal Teleki, Bela Imrady, Tibor Pataky - in the bishop's palace, and had the two ministers in his apartment in the castle building for a short time, but he did not negotiate with them ${ }^{158}$. He also acknowledged that, like all other Greek Catholic priests, on the instructions of the bishop, he wished Governor Miklós Horthy good health during the Mass ${ }^{159}$.

We know from the memoirs of Chira that Lieutenant Colonel Aksenov often wanted him to sign on what he had not said. He did not always agree to that ${ }^{160}$. Thus, the phrases "retreating fascist Hungarian troops" and "Soviet troops liberated Transcarpathian Ukraine" in his interrogation records are probably Aksenov's wording, as he mostly dictated his own words, not Chira's, to the stenographer ${ }^{161}$.

Father Istvan Bendasz was also placed in the prison in Uzhhorod, and we know from his writings that Chira was in cell No. 5 together with the Roman Catholic vicar Ferenc Pasztor from Berehove for a while. Also,

${ }^{151}$ BIGKKL. Chira Memoirs, 21.

152 Transcarpathian Regional State Archives. F. 2558. Op. 1. Ed. hr. 5392. P. 13-17.

${ }^{153}$ The answer to the latter two questions was that, under the influence of Péter Gebé, a distant relative, and from 1922. Transcarpathian Regional State Archives. F. 2558. Op. 1. Ed. hr. 5392. P. 18.

${ }^{154} \mathrm{He}$ answered this question by saying that the chaplain was an advisor to the bishop. And if for some reason there was no bishop, the chaplain was the governor of the eparchy via the vicar. Transcarpathian Regional State Archives. F. 2558. Op. 1. Ed. hr. 5392. P. 15.

${ }^{155}$ Transcarpathian Regional State Archives. F. 2558. Op. 1. Ed. hr. 5392. P. 23.

${ }^{156}$ Transcarpathian Regional State Archives. F. 2558. Op. 1. Ed. hr. 5392. P. 22.

${ }^{157}$ Transcarpathian Regional State Archives. F. 2558. Op. 1. Ed. hr. 5392. P. 14.

${ }^{158}$ Transcarpathian Regional State Archives. F. 2558. Op. 1. Ed. hr. 5392. P. 23.

${ }^{159}$ Transcarpathian Regional State Archives. F. 2558. Op. 1. Ed. hr. 5392. P. 24.

${ }^{160}$ BIGKKL. Chira Memoirs, 20.

161 BIGKKL. Chira Memoirs, 20. 
this is the source from which we know the daily routine of the prison: it started at 5 in the morning, at 7 o'clock the black sticky mud called bread (55 dkg) and the daily dose of sugar (9 grams), and the tea for breakfast, i. e. slightly stained boiling water were placed into the cell. Every other day, two bites of salted fish were added to the breakfast. Lunch at 1 o'clock in the afternoon - half a liter of "fat-free slop" with some cabbage, white beetroot and potato floating in it, and approx. 150-200 g. barley, oat, millet or corn porridge, rarely mashed potatoes, beans, peas. Dinner at 6: soup, similar to the lunch. A 10-15 minute walk a day, i. e. a "geese in a row" in a courtyard sized $10 \times 15 \mathrm{~m}$ surrounded by high walls. During the day, it was forbidden to lie down in the cell or take a nap while sitting, one could only talk in a low voice. Every ten days, a clipping machine was provided, and the prisoners were able to cut off each other's hair and beards. There was a very quick shower wash and laundry disinfection every ten days. During the sudden searches, people were stripped naked, the cell was subverted. The interrogations took place day and night, but mainly at night, one after another. A package could be received once a week, and it was thoroughly examined ${ }^{162}$.

Following a series of interrogations in Uzhhorod, according to the decision of the USSR Ministry of State Security of February 15, 1949, the prosecution continued at the Kiev Prison of the USSR Ministry of State Security ${ }^{163}$. He was transported by car from the Uzhhorod prison, accompanied by two officers, to Svaliava ${ }^{164}$, from where he arrived in Kiev, at the Korolenko Street prison on February 26, $1949^{165}$, where the most dangerous political prisoners were being investigated ${ }^{166}$. Here, Lieutenant Colonel Kharitonov, Deputy Commander of the Investigation Department of the Ukrainian MGB, interrogated him for several months. During the first days, he was placed in a strictly guarded solitary confinement for "his provocative conduct against the investigator" for three days as he denied the accusation of espionage and refused to sign a confession to it, even under strong coercion. In the solitary confinement, that is, in a cellar room with a cement floor, he received 200 grams of bread and hot water each day, it was forbidden to sit, lie down or take a nap during the day ${ }^{167}$. Each prisoner could write to his relatives about

\footnotetext{
${ }^{162}$ Bendász I. Öt év szögesdrót mögött... Ol. 86-89.

${ }^{163}$ Transcarpathian Regional State Archives. F. 2558. Op. 1. Ed. hr. 5392. P. 32.

${ }^{164}$ BIGKKL. Chira Memoirs, 21.

${ }^{165}$ Transcarpathian Regional State Archives. F. 2558. Op. 1. Od. zb. 5392. P. 33.

${ }^{166}$ Bendász I. Öt év szögesdrót mögött... O1. 149.

${ }^{167}$ BIGKKL. Chira Memoirs, 20-21.
} 
where he was. In the case of Chira, Kharitonov denied this opportunity, "No one should know about your whereabouts!", 168 . He offered him that if he "settles matters of an ecclesiastical nature" with the exarch of Kiev, he could fly home to Uzhgorod, but he refused ${ }^{169}$.

During the interrogations in Kiev, the authorities sought an answer to who were the members of the Christian People's Party in Czechoslovakia and Transcarpathian Ukraine. Based on the answers, the Christian People's Party in Czechoslovakia was founded by a priest of the Roman Catholic Church, Jan Srámek. In Transcarpathian Ukraine, the priest of the Greek Catholic Church, Avgustyn Voloshyn, and its members were mostly the Greek Catholic clergy, the intelligentsia (lawyers, doctors, teachers), the rich peasantry ${ }^{170}$. Also, they wanted to know what was the canon's opinion on the reunification of Transcarpathian Ukraine with Soviet Ukraine. He made it clear that he had not signed it, and a significant part of the Greek Catholic clergy refused to sign it because the church did not want to participate in politics $^{171}$.

He was forcibly demanded to explain what papal encyclicals he followed during his church service. Chira confessed that, among others, it was the "Actio Catholica", which appeared in 1925-26 and in which Pope Pius XI, to help the clergy, ordered the establishment of Catholic organizations to fight communist ideology and orthodoxy, and the encyclical "Ungodly Communism" that was published in 1937 against Communism. He confessed that in 1932-1933 Bishop Sztojka made him the leader of the "Actio Catholica" nothing for this papal encyclical, as before the publication of the encyclical in the Mukachevo Eparchy several active Catholic organizations formed against communist ideology, for the strengthening of Catholicism ${ }^{173}$. These were the Central Chancellery for the Protection of the Faith, the Congregation of Mary, the Rosary Society, and the St. Joseph Missionary Society. From 1924 to 1927 , he was the leader of the latter ${ }^{174}$.

Investigators thoroughly examined the literature published by the Greek Catholic Church. According to Chira's testimony in the transcript of the interrogation of March 19, 1949, the published journals - "Dushpastyr"

\footnotetext{
${ }^{168}$ BIGKKL. Chira Memoirs, 21.

${ }^{169}$ BIGKKL. Chira Memoirs, 21.

${ }^{170}$ Transcarpathian Regional State Archives. F. 2558. Op. 1. Ed. hr. 5392. P. 36.

${ }^{171}$ Transcarpathian Regional State Archives. F. 2558. Op. 1. Ed. hr. 5392. P. 40-43.

172 Transcarpathian Regional State Archives. F. 2558. Op. 1. Ed. hr. 5392. P. 44-45.

${ }^{173}$ Transcarpathian Regional State Archives. F. 2558. Op. 1. Ed. hr. 5392. P. 46-47.

${ }^{174}$ Transcarpathian Regional State Archives. F. 2558. Op. 1. Ed. hr. 5392. P. 48.
} 
(Official Gazette of the Eparchy), "Blahovesnyk", "Misiynyi visnyk", "Dushiynyi visnyk", "Dobryi pastyr" contained anti-Soviet propaganda to protect the believers against communist principles, since they persecute the church, religion, arrest priests, and close churches in the Soviet Union ${ }^{175}$. Communist ideas forbid the church from providing religious education to children ${ }^{176}$. He had published articles in the magazines "Dushpastyr" and "Dobryi pastyr", but did not admit that they were anti-Soviet ${ }^{177}$. However, he acknowledged his viewpoint, and for the aforementioned reasons, was hostile to communism, which was not manifested in his actions ${ }^{178}$. "I oppose all the actions of the Soviet power that force the Greek Catholic Church to convert to the Orthodox religion",179.

At his interrogation on April 11, 1949, when asked what he thought was the reason the church did not recognize Soviet power, he replied on behalf of the whole church that because "communist ideals reject religion, they do not recognize private property, they deprive the church of the right to teach children in a religious spirit; Soviet laws incite hatred towards Catholicism,"180.

At his interrogation on April 19, 1949, he declared that he was a staunch supporter of Catholicism and the Vatican, but did nothing against the Soviets $^{181}$.

Investigators found out that in the spring of 1948, Chira compiled the history of the Greek Catholic Eparchy of Mukachevo, which was handed over to Greek Catholic lawyer Foma Csekan, with whom he had maintained good relations for a long time, whom he had met and consulted several times about the future of the Greek Catholic Church under Soviet rule, and who was a representative of the People's Council in 1944-1945, and was close to the Soviet administrative bodies. Through Csekan he wanted to acheve the Soviet leadership not to liquidate the Greek Catholic Church. He hoped that they would be able to agree upon that and that the Greek Catholic Church could prove its loyalty to the Soviet power while maintaining its relationship with the Pope. Chekan suggested that the only solution was to approach Soviet power, to renounce Catholicism and convert to the Orthodox faith, as the hostility of the clergy to the Soviet state could trigger the persecution of

\footnotetext{
${ }^{175}$ Transcarpathian Regional State Archives. F. 2558. Op. 1. Ed. hr. 5392. P. 49-50.

${ }^{176}$ Transcarpathian Regional State Archives. F. 2558. Op. 1. Ed. hr. 5392. P. 68.

${ }^{177}$ Transcarpathian Regional State Archives. F. 2558. Op. 1. Ed. hr. 5392. P. 53.

${ }^{178}$ Transcarpathian Regional State Archives. F. 2558. Op. 1. Ed. hr. 5392. P. 68.

${ }^{179}$ Transcarpathian Regional State Archives. F. 2558. Op. 1. Ed. hr. 5392. P. 70.

${ }^{180}$ Transcarpathian Regional State Archives. F. 2558. Op. 1. Ed. hr. 5392. P. 67.

${ }^{181}$ Transcarpathian Regional State Archives. F. 2558. Op. 1. Ed. hr. 5392. P. 70-71.
} 
the Greek Catholic clergy. As it turned out at the end of the interrogation on May 14, 1949, that while in Chira's home, Chekan himself suggested writing a short history of the formation and activities of the church, to be used as factual material in consultations with representatives of the Soviet power in order to preserve the church ${ }^{182}$.

During the interrogation on May 27, 1949, the nationalist education of young people was surveyed. They were trying to demonstrate that in a self-training group at the priestly seminary, where there was a "Ukrainian and Russian trend" (Ukrainian students arrived from Berehove, Russians from Mukachevo), Chira, as a member of Voloshyn's Christian People's Party, supported Ukrainians and exhibited negative behaviour towards the Russian students ${ }^{183}$.

On April 1, 1949, deputy head of division No. 1 of the Investigation Department of the USSR Ministry of State Security, Lieutenant Colonel Kharitonov stated: "Chira has long been one of the leaders of the antiSoviet, nationalist Christian People's Party operating in Transcarpathian Ukraine. As an active Catholic missionary and a promoter of the ideas of Catholicism, he regularly preached anti-Soviet speeches to the local population. In addition, Chira is an agent of the Vatican, who engaged in espionage and passed on information about the Soviet Union to imperialist countries. After the establishment of Soviet power in Transcarpathian Ukraine, Chira systematically worked actively among the believers to strengthen Catholicism and spread hostile ideas about the Soviet Union. As for the listed allegations, Chira pleaded partly guilty. Chira must be interrogated further on in order to reveal all his anti-Soviet activities and to shed light on his system of contacts with foreign spies, which will take time",184. Based on this, the investigation was extended until July 10, $1949^{185}$.

Finally, after months of investigation and interrogation, on June 15, 1949, Lieutenant Colonel Kharitonov declared the investigation completed, having gathered sufficient evidence for the court. Pursuant to Article 206 of the Criminal Code, he presented the result of the investigation to the accused, who had nothing to add to it ${ }^{186}$.

\footnotetext{
${ }^{182}$ Transcarpathian Regional State Archives. F. 2558. Op. 1. Ed. hr. 5392. P. 80-84.

${ }^{183}$ Transcarpathian Regional State Archives. F. 2558. Op. 1. Ed. hr. 5392. P. 88-93.

${ }^{184}$ Transcarpathian Regional State Archives. F. 2558. Op. 1. Ed. hr. 5392. P. 136-137.

${ }^{185}$ Transcarpathian Regional State Archives. F. 2558. Op. 1. Ed. hr. 5392. P. 138-139.

${ }^{186}$ Transcarpathian Regional State Archives. F. 2558. Op. 1. Ed. hr. 5392. P. 144
} 
Chira was subjected to a medical examination, as a result of which a prison doctor, Gladenko, determined he was "healthy and capable of physical work ${ }^{, 187}$.

On June 18, 1949, he was indicted by the Soviet Special Council under the USSR Criminal Code Articles Btk. 54-4., 54-10.2. ${ }^{188}$ These were "supporting the international bourgeoisie, striving to overthrow the communist regime", and "counter-revolutionary propaganda and agitation, exploiting the religious prejudices of the masses". Among the accusations, the "anti-Soviet nationalist conspiracy" was highlighted.

Based on the indictment, on August 6, 1949, the 52-year-old Chira, was sentenced to 25 years of forced labor in Siberia (calculated from February 10, 1949) and total confiscation of property ${ }^{189}$, with "complete omission of trial and defense ${ }^{, 190}$.

According to the verdict, he was sent to Ozerni Gulag camp ${ }^{191}$ No. 7. in Tayset, abbreviated as "Ozerlag", in Siberia, one of the "Special Camps" for the most dangerous political prisoners, where he arrived on October 2, 1949. He worked in coal mines and various construction sites. From there, on August 19, 1951, he left for the Kamishevsky Labor Camp in Omsk County, or "Kamishlag", also known as Osoblag No. 10, created on April 30, 1951. He spent eight years in bondage ${ }^{192}$.

These restricted forced labor camps, special camps, were established in the spring of 1949 on the secret order of the Soviet Ministry of Internal Affairs, and their only advantage over the average forced labor camps was that they did not have any criminals, only political convicts ${ }^{193}$.

The "Ozerlag", where Sandor Chira was sent, included dozens of camp sections, with about 800-1200 political prisoners in the barracks of each section. Before the Second World War, it was an area intended for the construction of railway and hydroelectric power plants, as well as for deforestation and logging, which the Stalinist state machinery wanted to utilize by large-scale free labor. The doors of the camp barracks were

${ }^{187}$ Transcarpathian Regional State Archives. F. 2558. Op. 1. Ed. hr. 5392. P. 145.

${ }^{188}$ Transcarpathian Regional State Archives. F. 2558. Op. 1. Ed. hr. 5392. P. 150-152.

${ }^{189}$ Transcarpathian Regional State Archives. F. 2558. Op. 1. Ed. hr. 5392. P. 153.

${ }^{190}$ BIGKKL. Chira Memoirs, 22.

${ }^{191}$ Transcarpathian Regional State Archives. F. 2558. Op. 1. Ed. hr. 5392. P. 153.

192 Bendász I., Bendász D. Helytállás és tanúságétel... Ol. 24; Botlik J. Hármas kereszt alatt... O1. 286; Riskó M. Chira Sándor (1897-1983), a Munkácsi Görögkatolikus Egyházmegye püspökének élete és vértanúsága. Doktori $(\mathrm{PhD})$ értekezés. Budapest: PPKE BTK Történelemtudományi Doktori Iskola, 2017. Ol. 163.

${ }^{193}$ Bendász I. Öt év szögesdrót mögött... Ol. 167. 
locked after work, the prisoners could not be visited, they could only send one letter a year, which of course was censored. The barracks were heated by an iron stove set up at the entrance, which was not suitable to heat the entire room. Workers were released from working 9-10 hours a day if the temprature was below $-38^{\circ} \mathrm{C}$. They were punished in solitary confinement for the slightest misdemeanor ${ }^{194}$.

99\% of the convicted clergy of the Mukachevo Eparchy were suffering in these camps, where they heard several times a day that the purpose of the camps was for them "to perish as soon as possible and in great numbers $" 195$.

In Kamishlag, the sick Bishop Chira met one of his fellow villagers from Vilkhivtsi, Vasily Dash, who transferred him to his brigade and dismissed him from hard physical labour. He held masses at night, but was betrayed, so he was sent to a penalty camp ${ }^{196}$.

In the summer of 1953, Joachim Wolf, a former cellmate from the Kiev prison, found him at the Komishlag. He suffered from pneumonia 5 times during the camp years and his correspondence revealed that a tuberclosis cavity had formed in his right lung ${ }^{197}$. At that time, due to his poor health, Chira was no longer working on the construction site, but worked in a camp hospital and then as a duty worker in a barracks, cleaning, etc. He secretly held masses every day, and on Sundays and holidays in the presence of several believers. He made wine from raisins. He also wed camp supervisors and baptized their children ${ }^{198}$.

Stalin died in 1953 and the regime eased; Kamishlag was liquidated on October 4, 1954. After Stalin's death, the priests who survived the deportation to the camps returned home weak and tormented. Greek Catholic priests were completely forbidden to practice their vocation. They were constantly monitored, they were regularly summoned to the NKVD for questioning, and their flats were regularly searched ${ }^{199}$.

On May 24, 1956, Miklos Muranyi ${ }^{200}$, the apostolic vicar of the Mukachevo Greek Catholic Eparchy, was released from the Gulag by amnesty $^{201}$. On September 4, 1956, the Directorate of the Omsk County

\footnotetext{
${ }^{194}$ Riskó M. Chira Sándor (1897-1983)... Ol. 161-192.

${ }^{195}$ Bendász I. Öt év szögesdrót mögött... Ol. 167.

${ }^{196}$ Riskó M. «A jó harcot megharcoltam, a hitet megőriztem...»... O1. 171.

${ }^{197}$ BIGKKL. The letter by Sandor Chira to Andrea Stec. Karaganda, April 16, 1965.

${ }^{198}$ Riskó M. Chira Sándor (1897-1983)... Ol. 165.

${ }^{199}$ Brenzovics L. Az Ukrán Szovjet... Ol. 100.

${ }^{200}$ Marosi I. A Munkácsi Görögkatolikus Egyházmegye 1945. évi sematizmusa. Bendász Hagyatéksorozat. 3. Berehove: Szpektraly Ltd, 2020. O1. 22.

${ }^{201}$ Bendász D. A Munkácsi Görögkatolikus... Ol. 204.
} 
Correctional Labor Camps of the Ministry of Internal Affairs of the Soviet Union released Chira from camp punishment in accordance with the decision of Protocol No. $194^{202}$. Bishop Chira was allowed to return to Transcarpathia on August 6, $1956^{203}$.

After 1956, many priests returned from the Orthodox to the Greek Catholic Church ${ }^{204}$. " $<\ldots>$ The unitus priests asked to be allowed to function as a unitus congregation, and there were unitus priests who left the Orthodox Church. They were assisted and supported by several Roman Catholic priests, such as Pasztor, Bujalo, or Hudra <...>. Roman Catholic church leaders and priests should not be allowed to help the unitus church, its priests and their followers $<\ldots>$ "205, - states the report of M. Rasput'ko to P. Vilkhovyi on April 5, 1957.

The events of the Hungarian Revolution of 1956 had an impact on the situation of priests who had recently returned home from camps, but mainly on Miklos Muranyi, Istvan Bendasz and Sandor Chira. The KGB blamed them for the resurgence of secret priestly activity, as several people - Ivan Szlivka, Ivan Ivancso, Antal Bacskay, etc. withdrew their apostasy and returned to the Greek Catholic Church, some of them in writing, and, of course there was a tough reaction from the KGB to their decision $^{206}$.

How could the newly freed bishop react to the events of '56 according to Radio Free Europe news? "He stood by Mindszenty",207. He considered the ordination of the priests to be the most important for the rebirth and strengthening of the eparchy, so he ordained the almost graduated theologians and former students of the Theological College, which was liquidated in 1949. As a result of the severe persecution, only four of the 8 little priests finally undertook the oath in Uzhhorod, on November 7, 1956, in the apartment of the priest Todor Miskolc, and it was kept secret until $1990^{208}$.

The local leadership and KGB staff closely monitored the activities of Greek Catholic priests who returned home from the GULAG camps. Chira was re-arrested on January 17, 1957, just on his 60th birthday in

\footnotetext{
${ }^{202}$ Transcarpathian Regional State Archives. F. 2558. Op. 1. Ed. hr. 5392. P. 154.

${ }^{203}$ Transcarpathian Regional State Archives. F. 2558. Op. 1. Ed. hr. 5392. P. 155-157.

${ }^{204}$ Bendász D. A Munkácsi Görögkatolikus... O1. 211.

${ }^{205}$ Central State Archive of the highest authorities and administration of Ukraine.

F. 4648. Op. 4. Od. zb. 214. P. 31.

${ }^{206}$ Bendász I. Öt év szögesdrót mögött... Ol. 21.

${ }^{207}$ Riskó M. Chira Sándor (1897-1983)... Ol. 168.

${ }^{208}$ Bendász D. A Munkácsi Görögkatolikus... Ol. 204.
} 
his native village, when he was with his siblings ${ }^{209}$, but according to other sources he was re-arrested for his secret priestly activities during the sacred mass at Christmas ${ }^{210}$, and was exiled to Karaganda, Kazakhstan, on January 27, 1957 for 5 years ${ }^{211}$, along with with vicar Muranyi.

Sándor Chira and Miklós Murányi were able to join the pastoral activities already operating in Karaganda. Chira spoke German and Latin fluently, and Russian and Ukrainian mixed with the Ruthenian vernacular, and considered Hungarian to be his native language. He was immediately accepted by German Catholics.

In the outer district of Karaganda, in Majkoduk, consisting of 8-10 streets, popularly referred to as «German Berlin» and mostly inhabited by German settlers, Ukrainian and Baltic nationalists, he also could be the pastor for exiled Roman Catholic Poles, Lithuanians, Latvians, and Ruthenians from Transcarpathia ${ }^{212}$. He was taken in by Andreas Hermann and his wife Barbara. He worked in a coal mine, according to others, on the construction of the city theater until 1962, after that he was able to retire. Retired Chira was taken in by Elfrida Hermann's family - after Barbara got cancer and could no longer care for the father - there he lived for the remaining two decades of his life ${ }^{213}$.

On August 23, 1957, in order to cure his illness, the Soviet authorities miraculously allowed Miklos Muranyi to return home, where he immediately became the leader of the illegitimate Mukachevo Greek Catholic Eparchy. However, Chira remained the head of the priestly ordinations and the head of the eparchy, despite the fact that the KGB were paying particular attention to all the activities of the exiled Bishop Sandor Chira connected to the eparchy ${ }^{214}$. On January 25, 1958, the KGB tried to intimidate the released priests with nightly inspections, unexpected street attacks, and beatings on the grounds that they were working to resurrect the abolished Greek Catholic $\mathrm{Church}^{215}$. The correspondence was being surveyed aspecially. Therefore, Konstantin Szabo, Janos Szokol, and father Jozsef Holovacs traveled to Karaganda. Their journey was interrupted several times by the KGB, so bishop Chira saw the time had come for his eparchy to have a bishop in

\footnotetext{
${ }^{209}$ Riskó M. Chira Sándor (1897-1983)... Ol. 171-175.

${ }^{210}$ Bendász D. A Munkácsi Görögkatolikus... O1. 204.

${ }^{211}$ Transcarpathian Regional State Archives. F. P-1723. Op. 2. Od. zb. 239. P. 69.

${ }^{212}$ Botlik J. Hármas kereszt alatt... O1. 286.

${ }^{213}$ Riskó M. Chira Sándor (1897-1983)... Ol. 176-177.

${ }^{214}$ Bendász D. A Munkácsi Görögkatolikus... Ol. 204.

${ }^{215}$ Riskó M. Chira Sándor (1897-1983)... Ol. 178.
} 
Transcarpathia. He obtained a permit, travelled home, and on June 18, 1977, secretly ordained Konstantin Szabo a bishop, then on August 24, 1978, the priest Janos Szemedi in Onokivtsi, at the home of Jozsef Holovacs, and on March 15, 1983, he ordained Jozsef Holovacs himself $^{216}$. In addition to the bishops, Chira also ordained a total of 30-35 priests for the Mukachevo eparchy ${ }^{217}$.

In Karaganda, at the time of the Khrushchev Thaw, some family homes were turned into secret temples and separate rooms were set up for secret masses, which led to harassment, priest interrogations on the agenda at the Karaganda office of religious affairs. Not only Chira, but also the believers were often observed and interrogated ${ }^{218}$. Despite this and his old age, he traveled constantly, holding masses in various towns and villages, even in the small villages of Omsk County, situated a thousand kilometers away ${ }^{219}$.

The five-year exile expired in 1962, but it was only from 1964 that he was able to return home once a year for family visits and medical examinations under surveillance. During his stay at home, he stayed with his brother, Kornel, and most of the time Istvan Bendasz and Jozsef Holovacs, who lived near Uzhhorod, organized his stay and secret gatherings and consecrations. Because of this, later, when it was revealed after Chira's death that he had been a bishop, Bendasz was suspected of being the bishop's successor and an investigation was launched against him ${ }^{220}$.

In January 1979, bishop Chira flew home for the funeral of Miklos Muranyi and gave a short farewell speech at the end of the ceremony. His veiled message to the faithful present was that the Mukachevo Eparchy "was not dead, only sleeping". Following the funeral, KGB agents demanded that Sandor Chira leave Transcarpathia immediately and reported the incident to the competent religious office in Karaganda, which informed the Transcarpathian Soviet authorities in an official

${ }^{216}$ Málej J. «A szovjet hatóságok 1945 nyarán elvették a Várat, amely csaknem kétszáz éve a kispapok otthona volt». A kárpátaljai fópásztor Holovács József püspök vallomása életéröl, pályájáról». Hadju-Bihari Napló. LIV. Évf. 79. Sz. 1997. április 5. O1. 5.

${ }^{217}$ Бендас С., Бендас Д. Священики-мученики... С. 263.

218 «Родом из Караганды». 1 серия. URL: https://www.youtube.com/ watch?v=ZB0qkYrrrLM; «Родом из Караганды». 3 серия. URL: https://www.youtube.com/watch?v=j55t10vKc08; «Родом из Караганды». 3 серия. URL: https://www.youtube.com/watch?v=a7I5GQXLCi4

${ }^{219}$ Riskó M. Chira Sándor (1897-1983)... Ol. 177-179.

${ }^{220}$ Bendász I., Bendász D. Helytállás és tanúságétel... Ol. 124. 
reply that Sandor Chira, a resident of Karaganda, received a strict warning and an administrative fine (50 rubels) ${ }^{221}$.

For twenty years, he was applying for permission to build a church for his Roman Catholic adherents. On January 28, 1977, in Moscow, the Office of Religion, attached to the Council of Ministers of the Soviet Union, authorized the registration of the Roman Catholic parish of Karaganda $^{222}$. Although the Karaganda religious office postponed the permit to build the church, Sandor Chira's chaplain service was authorized on April 8, 1977, and on November 20, Chira was able to bless the foundation stone of St. Joseph's Church in Majkoduk. The house of God "must have the shape of standard houses on the outside. There should be no sign that there is a church inside" - the instruction stated. By the end of 1978, the Church of St. Joseph was completed, and, referring to his age (81), Chira assumed only auxiliary pastoral duties ${ }^{223}$.

According to his death certificate, he died of lung cancer on May 27, 1983, in Karaganda, Bendas remembered the date to be May 23, $1983^{224}$, and according to the tombstone it was May 26, $1983^{225}$. Despite all state bans, 15 priests said farewell to him, including Jozsef Holovacs on behalf of the Mukachevo Eparchy, evading the vigilance of the authorities. His pursuers feared him even after his death, as at the end of May, Transcarpathian persons could not be picked up as passengers on flights ${ }^{226}$.

The headquarters of the Transcarpathian State Security Committee and the Regional Prosecutor's Office posthumously rehabilitated ${ }^{227}$ Chira on 28 April 1989, and it was published in the March 12, 1990 issue of Zakarpatska Pravda ${ }^{228}$.

Sándor Chira set an example with his perseverance and deep faith, as he maintained his faith and loyalty to his followers and his church in all circumstances - intimidation, interrogation, camp work, exile, and

${ }^{221}$ Riskó M. Chira Sándor (1897-1983)... Ol. 187.

${ }^{222}$ Riskó M. Kárpátaljai Görögkatolikus Egyház kálváriája 1944-től a legalitás visszanyeréséig a visszaemlékezések tükrében. Magyar egyháztörténeti vázlatok. Regnum. Essays in Church History of Hungary. 1995. № 1-2. P. 193.

${ }^{223}$ Riskó M. Az eskü mindvégig kötelez... Ol. 30.

${ }^{224}$ Bendász I., Bendász D. Helytállás és tanúságétel... O1. 126.

${ }^{225}$ ««Господи! я пойду за Тобою, куда бы Ты ни пошел» Lk.9:57. URL : https://www.youtube.com/watch?v=mmiOfgAjZIo

${ }_{226}$ Bendász I., Bendász D. Helytállás és tanúságétel... Ol. 126.

${ }^{227}$ Transcarpathian Regional State Archives. F. 2558. Op. 1. Ed. hr. 5392. P. 158-165.

${ }^{228}$ Bendász I., Bendász D. Helytállás és tanúságétel... Ol. 130. 
poverty. He resisted the agitators. He contributed to the formation of the history of the Greek Catholic Church.

Thus, from 1949, the Greek Catholic Church operated only illegally, in secret. Masses, burials, baptisms, weddings took place at homes, the priests did catacomb work, similar to the early Christian catacomb churches $^{229}$, until the church was rehabilitated on December 13, 1989, when the Soviet government adopted a decree to restore the rights of the Greek Catholic Church in Transcarpathia.

Since large-scale Soviet state-approved immigration took place during the Soviet period, resulting in the strengthening of the Orthodox Church, after the Greek Catholics were officially able to exercise their faith again, they had to fight a real struggle for the recovery of their churches. However, in 1991, the priest seminary was reopened in Uzhhorod, and the training of religion teachers began ${ }^{230}$.

\section{CONCLUSIONS}

Persecution of religious people and churches during the soviet regime was permanent, and it did not really stop until the collapse of the Soviet system. People of all kind of religious beliefs were targeted for persecution. It wasn't matter if they were Catholic, Reformed, Jewish etc. To destroy the church and faith, they did not pick in methods, and used different frequently rough, rude and violent ways. All it was directed and committed by the Soviet Council of Ministers, the Soviet Government, the Communist Party and their executive bodies. Their main goal was to eradicate at all religion, church, and faith.

The Soviet Union, so the Communist state was totalitarian and that is why religion was taken as a competitor to their ideology. That is why they had imperturbable resistor and attitude towards religious people who had different worldviews and adored God and not obeyed absolutely completely the Party. Thus, discrimination against believers was typical

The authorities hoped that thanks to their policies, religion would be pushed out of the public sphere and losing ground would be erased from people's soul and mind.

People, openly speaking about their faith and belief in God, were often misunderstood and rejected by the atheist society.

${ }^{229}$ Pilipkó E. A «nemlétező» görög katolikus egyház müködése Kárpátalján 1949-től 1989-ig. Népi vallásosság a Kárpátmedencében / S. Lackovits E., Mészáros V. 6/I. kötet. Veszprém: Veszprém Megyei Múzeumi Igazgatóság, 2004. Ol. 277.

${ }^{230}$ Dupka G. Egyházüldözés Kárpátalján 1944-1991... Ol. 65. 
They sought to destroy the churches, or at least make them impossible to function. Angry part of the clergy, priesthood lost their job. It became common that churches were transformed into atheist museums, gyms, clubs, warehouses, and workshops. One particular form of atheist education was individual education of schoolchildren who were presumably from strongly religious families. It was a constant task for educators to portray churches as anti-progressive and anti-scientific in their classes. A teacher, a person in a uniform, a person working in a senior position was not allowed go to church.

\section{SUMMARY}

After Transcarpathia came under Soviet control from September 26 to October 28, 1944 the Hungarians of Transcarpathia endured many troubles due to the dictatorial measures of the Soviet authorities. On December 5, 1944, mass secularization took place, declaring the separation of church and state, church and school. In March 1945, the authority to register births, marriages, and deaths was taken away from churches and was made the responsibility of state bodies. The Decree on Family and Marriage played an important role in the line of legislative decrees of the People's Council. This allowed for a wedding without a church ceremony.

The decree No. 58 issued in Uzhhorod on April 20, 1945, stated, among other things, that the upbringing and education of youth in Transcarpathian Ukraine was the task of the state, the executive power was concentrated in the hands of the Public Education Commissioner of the People's Council. Denominational schools were nationalized. Religious education was permanently banned. Anyone who broke the law could count on the harsh consequences. Churches were not considered legal entities. In 1945-1946, ecclesiastical, parochial, and denominational school property was completely nationalized.

Congregations had to rent their own former churches from the state, and various taxes were imposed on them. If the tax had not been paid, the church was closed. People living at church schools, convents, parishes were evicted. In several places pastors and priests lived in rented accommodation. If a settlement wanted to keep its church, a large tax was imposed on it.

A significant part of the priests and pastors were imprisoned or taken to the Gulag, so the ones who stayed at home served in 3-4 villages. They mostly travelled between their congregations on foot or by bicycle both in winter and summer, in old clothing and worn-out shoes. Religious 
ceremonies outside the church, such as pilgrimages, processions, confirmation, and so on, were banned. The Transcarpathian Investigation Department of the State Security Office of the Ukrainian SSR constantly monitored the pastors and priests, collected data on them and sent reports to the Council of Religious Cults. Active members of the church were also constantly monitored. At regular intervals, usually every six months, but sometimes even more often, churches had to report on various churchrelated events, such as: how many people visited the church at Easter, how many church visitors were there on Sundays, how many communioners were there, whether there was an organ or harmonium in the church, how many government bonds the church had, and so on. A separate report was requested on the consecration ceremonies, including a written record of the ceremony, as well as reports on the renovations of the church, indicating the exact amounts and expenses. No money was given for this purpose, and in fact, as far as it was possible, the renovation was being prevented, for example, the necessary official permits were not issued, but it was the task of the local pastor to rebuild the church from various donations, i. e. "people's money". Failure to do so would result in the church being closed as it could be in life threatening condition and an accident could happen at any time.

After the arrival of the Red Army in Transcarpathia, the clergy of the Greek Catholic Eparchy of Mukachevo did everything in their power to keep the oath they had taken before Bishop Miklós Dudás. With the exception of six people, they did not leave their designated positions.

In 1943, Stalin restored the Moscow Orthodox Patriarchate, thus deciding the fate of the Greek Catholic Church. We know from Romzha's report that in the Eparchy of Mukachevo, 306 priests served in 447 churches before the "unification".

The liquidation of the Greek Catholic Church, which was considered an enemy, was first initiated in Galicia, as there was a total of 5 million believers in the Soviet Union who practically lived in western Ukraine and who provided support for the independence of the Ukrainian state, not recognizing Soviet authority. Shortly after the invasion of the Red Army, Havryl Kostelnik, a great defender of Orthodoxy, organized an initiative group whose task was to "reunite" the Greek Catholic Church in Galicia with the Russian Orthodox Church. The Church General Assembly was held in March 1946 in Lviv, according to the scenario developed by the State Security Service. The Greek Catholic Ecclesiastical Assembly repealed the Decree of the Brest Union of 1596 on ecclesiastical union, were published. With this, the church seceded 
from the jurisdiction of the Vatican and merged with the Russian Orthodox Church.

The same scenario was intended to be applied in Transcarpathia, but the circumstances here did not allow it, as the region was bordered by several countries, so there was a risk of a possible international conflict. In addition, not only ecclesiastical but also familial relations united the population with the Roman Catholic Church, which was notoriously averse to both the Communists and the Orthodox church. Therefore, the representatives of the Soviet authorities carried out the liquidation of the Greek Catholic Eparchy of Mukachevo gradually, for which, among other things, they began to look for tangible, anti-Soviet accusations in the episcopal library; they increased terror, psychological pressure on the bishop, the priests, and so on. The Soviet authorities increasingly urged Greek Catholic parishes to convert to the Orthodox faith. They succeeded in part, but a significant proportion of the believers became Roman Catholic instead. Others secretly exercised their faith between 1949 and 1989, operating in illegality as a catacomb church. Masses, burials, baptisms, weddings took place at homes, until the church was rehabilitated on December 13, 1989, when the Soviet government adopted a decree to restore the rights of the Greek Catholic Church in Transcarpathia.

The Soviet leadership hoped that priests would grow old, die, there would be no replacement, churches would be depopulated, the church would disappear and eventually the atheist worldview would prevail. The leaders of the state tried to destroy the sense of religiosity from society in every possible way, to exterminate the faith from the consciousness of the population. The existence and activities of religious communities were incompatible with the concept of the moral and political unity of the Soviet people, but churches and faith survived to soviet regime.

\section{REFERENCES}

1. Archives of the Transcarpathian Reformed Diocese. Administrative documents. F. I. 10. C. February 2, 1956.

2. Archives of the Transcarpathian Reformed Diocese. Administrative documents. F. I. 10. C. February 4, 1957.

3. Archives of the Transcarpathian Reformed Diocese. Administrative documents. F. I. 10. C. February 14, 1957.

4. Archives of the Transcarpathian Reformed Diocese. Circulars. F. I. 10. C. December 4, 1961.

5. Archives of the Transcarpathian Reformed Diocese. Supreme authority circulars. F. I. 10. C. January 29, 1957. 
6. Archives of the Transcarpathian Reformed Diocese. Supreme Authority Circulars. F. I. 10. C. February 4, 1957.

7. Central State Archive of the highest authorities and administration of Ukraine. F. 4648. Op. 4. Od. zb. 114. P. 22.

8. Central State Archive of the highest authorities and administration of Ukraine. F. 4648. Op. 4. Od. zb. 214.

9. Transcarpathian Regional State Archives. F. 1. Op. 1. Delo Nr. 3485.

10. Transcarpathian Regional State Archives. F. 151. Op. 13. Delo Nr. 1511.

11. Transcarpathian Regional State Archives. F. 151. Op. 18. Ed. hr. 1715.

12. Transcarpathian Regional State Archives. F. 151. Op. 24. Delo Nr. 802.

13. Transcarpathian Regional State Archives. F. 151. Op. 24. Delo Nr. 964.

14. Transcarpathian Regional State Archives. F. 454. Op. 7. Ed. hr. 4.

15. Transcarpathian Regional State Archives. F. 454. Op. 7. Ed. hr. 6.

16. Transcarpathian Regional State Archives. F. 2558. Op. 1. Ed. hr. 5392.

17. Transcarpathian Regional State Archives. F. P-14. Op. 1. Szpr. 662.

18. Transcarpathian Regional State Archives. F. P-14. Op. 1. Szpr. 663.

19. Transcarpathian Regional State Archives. F. P-14. Op. 1. Szpr. 666.

20. Transcarpathian Regional State Archives. F. 2558. Op. 1. Ed. hr. 5392.

21. Transcarpathian Regional State Archives. F. 2558. Op. 1. Ed. hr. 5393.

22. Transcarpathian Regional State Archives. F. P-14. Op. 1. Od. zb. 1. «a».

23. Transcarpathian Regional State Archives. F. P-14. Op. 1. Szpr. 660.

24. Transcarpathian Regional State Archives. F. P-14. Op. 1. Szpr. 661.

25. Transcarpathian Regional State Archives. F. P-14. Op. 1. Od. zb. 665.

26. Transcarpathian Regional State Archives. F. P-14. Op.1. Szpr. 667.

27. Transcarpathian Regional State Archives. F. P-14. Op. 1. Od. zb. 702.

28. Transcarpathian Regional State Archives. F. P-1490. Op. 1. Delo Nr. 1.

29. Transcarpathian Regional State Archives. F. P-1490. Op. 1. Delo Nr. 2.

30. Transcarpathian Regional State Archives. F. P-1490. Op. 1. Delo Nr. 3.

31. Transcarpathian Regional State Archives. F. P-1490. Op. 1. Delo Nr. 12.

32. Transcarpathian Regional State Archives. F. P-1490. Op. 1. Delo Nr. 16.

33. Transcarpathian Regional State Archives. F. P-1490. Op. 1. Delo Nr. 17.

34. Transcarpathian Regional State Archives. F. P-1490. Op. 1. Delo Nr. 24.

35. Transcarpathian Regional State Archives. F. P-1723. Op. 2. Od. zb. 239. P. 69.

36.Az elítélt és kivégzett görögkatolikus papokról összegyüjtött adattár. Kárpátaljai Magyar Gulág-lexikon / Dupka (ed.). Uzhhorod Budapest: Intermix Kiadó, 1999.

37.Bendász D. A Munkácsi Görögkatolikus Egyházmegye a szovjet megszállás után és ma. A kommunizmus áldozatai, rehabilitációs alternativák Kelet-Közép-Európában / Molnár D.E., Molnár D.I. (ed.). 
Berehove: II. RFKMF Lehoczky Tivadar Társadalomtudományi Kutatóközpont, 2016.

38. Bendász I. Greek Catholic Library and Archives. Chira Sándor hagyatéki iratai. Visszaemlékezés. Karaganda, July 14, 1958. P. 1.

39. Bendász I. Öt év szögesdrót mögött. Egy kárpátaljai görög katolikus pap naplója a Gulágon. Uzhhorod: Harmadik bővített kiadás, 2012. Ol. 4.

40. Bendász I. Részletek a Munkácsi Görög Katolikus Egyházmegye történetiből. Uzhhorod: CLIO, KMKSZ, 1999. Ol. 118.

41.Bendász I., Bendász D. Helytállás és tanúságétel. A Munkácsi Görög Katolikus Egyházmegye hitvalló és meghurcolt papjai. Uzhhorod - Budapest: Galéria-Écriture, 1994.

42. Bohán B. Adalékok a Szatmári Egyházmegye XX. századi történetéhez. Egyháztörténeti Vázlatok. 2007. № 19. Évf. 3-4. Szám. 113-142.

43. Botlik J. Egestas Subcarpathica. Adalékok az ÉszakkeletiFelvidék és Kárpátalja XIX-XX. Századi történetéhez. Budapest: Hatodik Síp Alapítvány, 2000. O1. 285-286.

44. Botlik J. Hármas kereszt alatt. Görög katolikusok Kárpátalján az Uzhhorodi uniótól napjainkig (1946-1997). Hatodik Síp Alapítvány. Budapest: Új Mandátum Könyvkiadó, 1997. 274 ol.

45. Brenzovics L. Az Ukrán Szovjet Szocialista Köztársaság Kárpátontúli területe, 1945. június - 1991. augusztus. Kárpátalja. MTA Regionális Kutatások Központja / Baranyi Béla (ed.). Pécs - Budapest : Dialóg Campus Kiadó, 2009. O1. 100.

46.Dupka G. Koncepciós perek magyar elitéltjei. A sztálinizmus áldozatainak emlékkönyve (1944-1957). Uzhhorod-Budapest: Intermix Kiadó, 1993.

47.E. A Kárpátaljai görögkatolikus egyházról. Hatodik Síp, 1990. Június. Ol. 20.

48.Élő történelem. A Sztálini haláltáborok túlélőinek vallomásai 1944-1957 / Dupka G. (ed.). Uzhhorod - Budapest: Intermix Kiadó, 1993.

49. Fedinec Cs. Fejezetek a kárpátaljai magyar közoktatás történetéböl (1938-1991). Nemzetközi Hungarológiai Központ. Budapest, 1999.

50. Fodor G. Kárpátalja szovjetizálásának hatásai a Kárpátaljai Református Egyház életére 1944-1954 között. Szovjet fogságba hurcolt reformátusok a Kárpát-medencében. Tanulmánykötet / Erdős K. et al. (ed.). Debrecen, 2017. Ol. 181-182; Móricz K. Kárpátalja Sorsfordulói. Budapest: Hatodik Síp Alapítvány, 2001. 140 ol. 
51.Fodor G. A Kárpátaljai református egyház élete a sztálini egyházpolitika szorításában. A kommunizmus áldozatai, rehabilitációs alternativak Kelet-Közép Európában / Molnár D.E., Molnár D.I. Berehove: II. Rákóczi Ferenc Kárpátaljai Magyar Főiskola, 2016. Ol. 181.

52. Gönczi A. A görögkatolikus egyház felszámolása. Kárpátalján az Orosz Föderáció Állami Levéltára anyagainak tükrében. Értékek és kihívások / Gazdag V., Karmacsi Z., Tóth E. (eds.). II. kötet. Uzhhorod: Autdor - Shark, 2016. Ol. 41-48.

53.Gönczi A. Ruszin skizmatikus mozgalom a XX század elején. Uzhhorod - Berehove, 2008.

54.Gulácsy L. A mélységből a magasba. Bizonyságtétel az elmúlt időkről. Magánkiadás. 2009. Ol. 61.

55.Dupka G. Egyházüldözés Kárpátalján 1944-1991. A Gulágra elhurcolt és megtorlásban részesült kárpátaljai római katolikus, görögkatolikus papok, református lelkipásztorok és más felekezetek vezetőinek emlékére. Uzhhorod - Budapest: Szolyvai Emlékparkbizottság - Intermix Kiadó, 2017.

56. Hodinka A. A munkácsi görög-katolikus püspökség története. Budapest: Magyar Tudományos Akadémia, 1909.

57.Kárpátalja évszámokban 1867-2010 / Vehes M. et al. (ed.). Uzhhorod: Hoverla, 2011.

58. Majnek A. A Kárpátaljai római katolikus egyház története / Tóth I. et al. (eds.), Uzhhorod: Útközben. Tanulmányok a kárpátaljai magyarságról, 1998.

59. Málej J. “A szovjet hatóságok 1945 nyarán elvették a Várat, amely csaknem kétszáz éve a kispapok otthona volt". A kárpátaljai főpásztor Holovács József püspök vallomása életéről, pályájáról». Hadju-Bihari Napló. LIV. Évf. 79. Sz. 1997. április 5. O1. 5.

60. Marosi I. Görögkatolikus Magyarok Kárpátalján. Nagybégány Berehove: Szent Miklós Egyesület, 2014.

61. Marosi I. A Munkácsi Görögkatolikus Egyházmegye 1945. évi sematizmusa. Bendász Hagyatéksorozat. 3. Berehove: Szpektraly Ltd, 2020. Ol. 22.

62.Mihály Z., Zombori I. Az egyház hatalma - a hatalom egyháza. Budapest: METEM, 2015.

63. Oficinszkij R. A görög katolikus püspökség felszámolása. Kárpátalja 1919-2009 történelem, politika, kultúra / Fedinec Cs., Vehes M. (eds.). Hely nélkül: Argumentum, MTA Etnikai-nemzeti Kisebbségkutató Intézete, 2010. O1. 294. 
64. Oficinszkij R. A szovjet időszak sajátosságai Kárpátalja történetében. Kárpátalja 1919-2009 történelem, politika, kultúra / Fedinec Cs., Vehes M. (eds.). Hely nélkül: Argumentum, MTA Etnikainemzeti Kisebbségkutató Intézete, 2010.

65. Oficinszkij R. Egyházellenes intézkedések. Kárpátalja 1919-2009 történelem, politika, kultúra / Fedinec Cs., Vehes M. (eds.). Hely nélkül: Argumentum, MTA Etnikai-nemzeti Kisebbségkutató Intézete, 2010. O1. 289.

66. Oficinszkij R. Megtürt pravoszlávok és üldözött reformátusok. Kárpátalja 1919-2009 történelem, politika, kultúra / Fedinec Cs., Vehes M. (eds.). Hely nélkül: Argumentum, MTA Etnikai-nemzeti Kisebbségkutató Intézete, 2010. O1. 296.

67. Oficinszkij R. Szekularizáció szovjet módra. Kárpátalja 1919-2009 történelem, politika, kultúra / Fedinec Cs., Vehes M. (eds.). Hely nélkül: Argumentum, MTA Etnikai-nemzeti Kisebbségkutató Intézete, 2010. O1. 289.

68. Pekar A. B. «Tanúim lesztek». Adalékok a kárpátaljai görög katolikus egyház vértanúságához. Miskolc: Felsőmagyarország Kiadó, 2003. Ol. 13-16.

69. Pilipkó E. A «nemlétező» görög katolikus egyház müködése Kárpátalján 1949-től 1989-ig. Népi vallásosság a Kárpátmedencében / S. Lackovits E., Mészáros V. 6/I. kötet. Veszprém: Veszprém Megyei Múzeumi Igazgatóság, 2004. O1. 277.

70. Puskás L. Romzsa Tódor püspök élete és halála. H. n. : Don Bosco Kiadó Bt, 1998. Ol. 89-283.

71.Puskás L. Gondolatok az orosz ortodox egyház 20. századi történetéből. Lapszéli jegyzetek az Orosz Ortodox Egyház története első magyar nyelvü kiadásához. Teológiai-Hittudományi Folyóirat. № 34. Évfolyam, 3-4. Szám, 2000. O1. 130.

72. Riskó M. «A jó harcot megharcoltam, a hitet megőriztem...». Betekintés Chira Sándor püspök életútjába a források tanúságával». Acta Academiae Beregsasiensis / Orosz I., Szikura J. P. II. Berehove Uzhhorod : RFKMF, 2014. 13 évf. 1. k., Ol. 168.

73. Riskó M. Az eskü mindvégig kötelez. A kárpátaljai görög katolikus egyház kálváriája 1944-1991. Uzhhorod - Budapest : Intermix Kiadó, 1995.

74. Riskó M. Chira Sándor (1897-1983), a Munkácsi Görögkatolikus Egyházmegye püspökének élete és vértanúsága. Doktori $(\mathrm{PhD})$ értekezés. Budapest : PPKE BTK Történelemtudományi Doktori Iskola, 2017. Ol. 163. 
75. Riskó M. Kárpátaljai Görögkatolikus Egyház kálváriája 1944-től a legalitás visszanyeréséig a visszaemlékezések tükrében. Magyar egyháztörténeti vázlatok. Regnum. Essays in Church History of Hungary. 1995. № 1-2. P. 193.

76. Romzsa Tódor püspök hitvallása és vértanúhalála. Készült Puskás László atya boldoggáavatási életrajzi anyagai nyomán / Rozália R. Bulecza (ed.). Uzhhorod - Budapest : Intermix Kiadó, 2000.

77. Szabó G., father. Tövises út az egységhez. Fejezetek a kárpátaljai görög katolikus egyház történetéböl. Uzhhorod - Budapest : Intermix Kiadó, 1999. Ol. 73.

78. Szantner V. A Hajdúdorogi Egyházmegye története a kezdetektől 1920-ig. Eötvös Loránd Tudományegyetem Bölcsészettudományi Kar, Történettudományi Doktori Iskola. D. n. 10.

79. Vida I., Zseliczky B. Az 1945. június 29-ei szovjet - csehszlovák szerződés Kárpátaljáról. Külügyi Szemle. 2004. Tavasz - nyár.

80.Бендас С., Бендас Д. Священики-мученики, сповідники вірності. Ужгород : Закарпаття, 1999. С. 397-402.

81. «Господи! я пойду за Тобою, куда бы Ты ни пошел» Lk. 9:57. URL: https://www.youtube.com/watch? $\mathrm{v}=$ mmiOfgAjZIo

82.Пекар А.В. Нарис історї Церкви Закарпаття. Т. 1: Єрархічне оформлення. Рим - Львів, 1967. С. 193.

83.«Родом из Караганды». 1 серия.

URL: https://www.youtube.com/watch?v=ZB0qkYrrLM

$\begin{array}{lllll}84 . \ll \text { иодом из Караганды». } & 3 & \end{array}$

URL: https://www.youtube.com/watch?v=j55t10vKc08

85.«Родом из Караганды». 3 серия.

URL: https://www.youtube.com/watch?v=a7I5GQXLCi4

Information about the author: Varadi Nataliia Fedorivna,

Candidate of Historical Sciences, Lecturer at the Department of History and Social Sciences Ferenc Rakoczi II Transcarpathian Hungarian College of Higher Education

31, Csajkovskij str., Beregovo, Transcarpathian region, 90202, Ukraine 